\title{
An Integrated Waste-Free Biomass Utilization System for an Increased Productivity of Biofuel and Bioenergy
}

\author{
László Kótai et al.* \\ Institute of Materials and Environmental Chemistry, Chemical Research Center, \\ Hungarian Academy of Sciences, \\ Hungary
}

\section{Introduction}

The increase in production and utilization of biomass and other renewable sources of energy are important challenges of the energy industry. It generates, however, demands for ecologically and economically acceptable production systems. Here we report an integrated system of known and new technologies developed for biomass conversion to biofuels. This includes classical and biobutanol based new biodiesels, biogas and electricity production, and an agricultural production system involving fertilization with the ash of the biomass power plants. Basically, three types of agricultural production system are needed for the agricultural segment of the integrated system, namely:

A - plants for combustion in biomass power plants (energy grass)

$\mathrm{B}$ - plants for production of vegetable oils for biodiesel production

$\mathrm{C}$ - plants for conversion of sugar derivatives to price alcohols, mainly butanol as a diesel fuel source

Depending on the climate, the soil type, the agricultural experiences, and the type of the plants $(\mathrm{A}, \mathrm{B}, \mathrm{C})$, the produced biomass materials can fulfill more than one requirement as it can be seen in Fig. 1. Depending on the constituents of the biomass (cellulose, starch, lignin, oil, proteins), the energy production can be performed via direct combustion or, after digestion in biogas systems, by using the biogas. The biomass power plants, biogas combustion plants/engines produce hot water, steam and electricity. In plants type B soybean, rape, sunflower or likes are pressed to obtain the oil, while the pressing cake can be used as optimal raw material for biogas plants due to its high protein content, while the

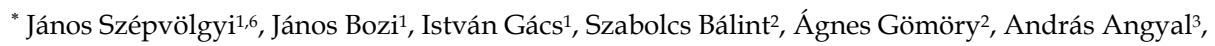
János Balogh ${ }^{4}$, Zhibin $\mathrm{Li}^{5}$, Moutong Chen ${ }^{5}$, Chen Wang ${ }^{5}$ and Baiquan Chen ${ }^{5}$

1 Institute of Materials and Environmental Chemistry, Chemical Research Center,

Hungarian Academy of Sciences, Hungary,

2 Institute of Structural Chemistry, Chemical Research Center, Hungarian Academy of Sciences, Hungary,

3 Axial-Chem Ltd., Hungary,

4 Kemobil Co., Hungary,

5 China New Energy Co., China,

6 Research Institute of Chemical and Process Engineering, University of Pannonia, Hungary.
} 
stalk can also be used as solid fuel (after drying with the low heating value warm water) in biomass power plants. Generally, the green biomass can be utilized in biogas plant and the dried ones as solid combustion fuel in power plants. The residues of the sugar derivatives producing plants (sugar sorghum, corn, etc.) can supply a biomass power plant with their dried stalk. The complete waste processing in these energy producing units and recirculation of other wastes (potassium sulfate, calcium sulfate or biomass power plant ash) of the integrated system as fertilizers into the agriculture contribute to a sustainable biomass production and fuel production, as well.

\section{Energy aspects of biomass utilization}

The intensive production of biomass as raw material for fuel or bioenergy production would lead to fast exhausting of the soil and dramatic increasing the production costs without intensive fertilization. Except nitrogen, all of the nutrients $(\mathrm{P}, \mathrm{K})$ and microelements can be recycled by reprocessing the residues of the biomass work up or biomass utilizing energy producing technologies. The nitrogen fertilization, however, always requires fossil energy source, since the base material of the two most typical nitrogen fertilizer (ammonia and urea) is the natural gas. It is one of the main reasons of the opposite statements about energy intake and output balance of the biomass based fuel and energy productions. Otherwise, the conversion of the waste to fertilizers (to supply other elements like P, K, S and microelements) should also be the integrated part of the sustainable and economic biomass production system.

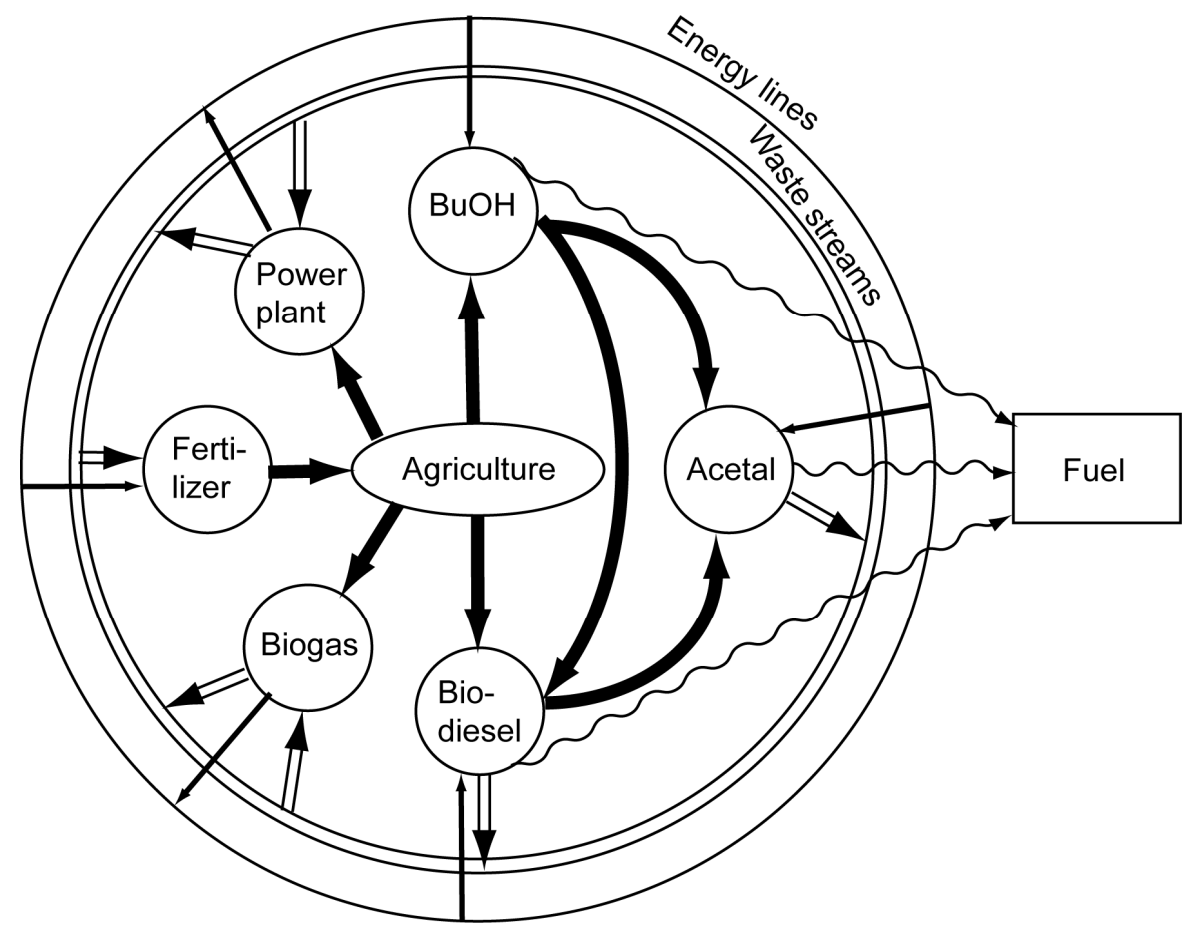

Fig. 1. Waste free biofuel production cycle 
The review of the energy inputs required for the production of the raw materials like corn, switchgrass or sunflower, or the cost of the biofuel production form these agricultural materials (Pimental and Petzek, 2005) unambiguously show, that the climate (crop amount), type of the agricultural plant and the type of the processing technologies basically determines the feasibility of an energy positive biofuel production. The energy saving in the production of the various biofuel components from various sources is compared to the production costs related to petrochemical raw materials (Arlie, 1983) is given in Table 1. Selection of the biomass produced and the fuel type prepared from this biomass requires that environmental, economic and energetic viewpoints (Hill et al., 2006) should also be taken into consideration. The social-economic viewpoints play also key role in this decision. That is obvious, that there is not any type of biomass plant which could completely be turned into biofuel, only integrated systems can solve this problem, when more than one type of biomass plants are in synchronized operation. More than one energy producing system is used to utilize the various type of green biomass, and more than one type of biofuel are produced from the various parts of each type of biomass plants. At the same time the energy producing plants or the waste producing and nutrient reprocessing plant (fertilizer plant) can use the wastes of each technological step as raw material to ensure the recyclability.

\begin{tabular}{|c|c|c|c|}
\hline Product & Petrochemical source & Biomass & Energy gain \\
\hline $\mathrm{MeOH}$ & Natural gas & Wood & 0.60 \\
\hline \multirow{3}{*}{$\mathrm{EtOH}$} & \multirow{3}{*}{ Ethylene } & Sugarcane & 0.73 \\
\hline & & Artichoke & 0.88 \\
\hline & & Corn & 0.65 \\
\hline \multirow{3}{*}{ n-BuOH } & \multirow{3}{*}{ Propylene } & Sugarcane & 0.10 \\
\hline & & Artichoke & 0.75 \\
\hline & & Wheat straw & 0.80 \\
\hline \multirow{3}{*}{ Acetone } & \multirow{3}{*}{ Propylene } & Sugarcane & 0.80 \\
\hline & & Artichoke & 1.45 \\
\hline & & Wheat straw & 1.51 \\
\hline
\end{tabular}

Table 1. Energy gain of sugar-based biofuel components (ton of oil equivalent/ton)

Since the energetically favorable components as $\mathrm{BuOH}, \mathrm{EtOH}$ and acetone can be produced from biomass the use of these in biofuel including biodiesel production seems to be essential and unavoidable step. The EU biofuel standards now declare that rapeseed oil and ethanol as raw materials are permitted and standardized as biofuels within European Community. Due to the limits of the agricultural area and the productivity of rape in this climate and low energy content of ethanol, however, requires changing this statement and the use of other type of biofuels should be also permitted. Thus, in our integrated system we incorporate new type of blend materials, mainly butanol for replacing the ethanol, and new kind of blends are produced from the wastes of biodiesel and biobutanol production as well. In order to increase the amount of biodiesel produced from one unit of vegetable oil, butyl ester production is suggested instead of the methyl esters, and butoxylation or blending with pure butanol are also possible increments in increasing the efficiency of the biofuel production related to one hectare of the agricultural area. 


\section{New trends in biodiesel technologies}

The new developments in biodiesel production technologies are focused on simplification of the existing technologies by using co-solvents (Guan et al., 2009b), supercritical solvents (Geuens et al., 2008), new catalysts (including heterogeneous and biocatalysts) (Fu and Vasudevan, 2009; Soriano et al., 2009; Leung et al., 2010) and the efforts are directed on founding new blends and raw materials (including the waste glycerol (Guerrero-Perez, et. al., 2009)) to increase the amount of biofuel produced on a given agricultural area. Some of the improved methods are discussed below.

\subsection{Trans-esterification with phase mixing materials}

Base catalyzed trans-esterification of the vegetable oils with methanol is a slow process in the two-phase system due to the mass transfer limitation. The butanolysis is much faster because it takes place in homogeneous phase. Therefore, the possibilities to create a homogeneous mixture by using an appropriate co-solvent which homogenizes the vegetable oil and methanol has extensively been studied (Guan et al., 2009a; 2009b; Leung et al., 2010; Meng et al., 2009; Soiano et al., 2009). The best solvents are the ether-type compounds like THF, methyl tertiary butyl ether, $\mathrm{Me}_{2} \mathrm{O}$ or diethers. Phase diagrams of different vegetable oils - ethereal solvents (1,4-dioxane, THF, $\mathrm{Et}_{2} \mathrm{O}$, diisopropyl ether and MTBE)-methanol have been studied (Boocok et al., 1996a) and THF was found to be the preferred solvent on the basis of the volume required by the miscibility and boiling point considerations. Initially the reactions are very fast, but they slow down drastically due to the polarity changes in the mixed phase containing esters and decreasing amount of alcohol [Boocock et al., 1998). The decreasing polarity of the intermediate mixture could be avoided only by using large excess of methanol (methanol/oil molar ratio 27) when the methyl ester production exceed $94.4 \%$ in $7 \mathrm{~min}$ even at room temperature. The separation of the glycerol phase in the presence of THF was much more rapid as in the case of two-phase trans-esterification reaction mixtures (Boocock et al., 1996a). The use of cyclic THF or 1,4-dioxane provides a possibility to decrease the amount of the co-solvent and perform the trans-esterification at higher oil : cosolvent ratios. The THF and the dioxane are miscible with vegetable oils and methanol in any proportion and they have hydrogen bonding ability (Boocock et al., 1996b). In spite of that $5 \%$ dioxane ensures almost complete reaction within $30 \mathrm{~min}$ at room temperature at a 6:1 methanol : oil molar ratio, the 1,4-dioxane ring opens up during the trans-esterification reaction at the presence of $1 \% \mathrm{KOH}$ catalyst, thus it cannot be recycled at all.

Dimethyl ether can be separated easily with depressurizing the reaction system and $\mathrm{Me}_{2} \mathrm{O}$ as a polar compound ensures a sufficiently high trans-esterification reaction rate at room temperature. The effects of the reaction conditions on the reaction time indicated that under the usual conditions, such as $1 \%$ of $\mathrm{KOH}$ and 2-fold molar excess of methanol (6:1 methanol : oil molar ratio), the reactions can be performed within 5-10 min which would provide a good technological base for the continuous production of biodiesels (Guan et al, 2009a and $2009 \mathrm{~b}$ ). The gaseous state of form of the $\mathrm{Me}_{2} \mathrm{O}$ requires pressurized reactors and the risk of explosion is very high.

Recently a new technology has been developed (Kótai et al., 2008) for the phase-mixing of methanol (or other alcohols) and vegetable oils in trans-esterification reactions with alkoxyalkanol phase transfer agents. These are hemi-ethers of glycols. They are polar endgroup, but they have oil-soluble alkyl chain as well. The best candidate is the butylglycol (2butoxy-ethanol), which can act at even $1 \%$ concentration, and at the $6: 1 \mathrm{MeOH}$ : rapeseed 
oil molar ratio with $1 \% \mathrm{KOH}$ a catalyst. The reaction is almost completed within $30 \mathrm{~min}$ even at room temperature. By using $5 \%$ of butylglycol, the reaction time is $5-10 \mathrm{~min}$. Since the butyl glycol acts also as an alcohol (not only as an ether), thus not only methyl esters but 2-butoxyethyl esters - $\mathrm{R}-\mathrm{C}(\mathrm{O})-\mathrm{O}-\mathrm{C}_{2} \mathrm{H}_{4}-\mathrm{OC}_{4} \mathrm{H}_{9}$ - are also formed. These esters are formed in an amount of $2-3 \% \mathrm{w} / \mathrm{w}$ and act as fuel components. In this way, the phase mixing agents built into the ester phase and they contribute to the mass of the biodiesel and do not need to recover it which simplifies the production technology. The catalyst solution prepared from $\mathrm{KOH}$, butylglycol and methanol was used in our plant scale experiment performed in Hungary in 2009, when a continuous trans-esterification process with continuous separator was put into operation. The method could be combined with the ion exchange type removal and recycling of the neutralization agent $\left(\mathrm{KHSO}_{4}\right.$, chapter 3. 2), because the reaction takes place at room temperature and the amount of soaps formed and appeared in the ester phase was very small. The catalyst distribution between the ester and glycerol phase is around 2:98. The ester phase has been neutralized with $\mathrm{KHSO}_{4}$, when the potassium content is decreased with the continuous operation mode below $50 \mathrm{ppm}$ without any further washing. The further purification steps, washing with water and removing the residual $\mathrm{MeOH}$ in vacuum, are the same as in the classical biodiesel technologies, however, the amount of the dissolved $\mathrm{MeOH}$, due to the lack of soaps and residual catalyst is much lower than in the usual technologies. The flow-sheet of the technology is shown in Fig 2.

In order to decrease the length of the tube reactor and the residence time of the mixture in the apparatus, a two-stage trans-esterification seems to be the most reliable, when after decreasing the rate of the reaction, after the first separator a further amount of methanol and catalyst are added, when the reaction rate is suddenly increases: it is attributed to the extra methanol ensuring a large excess for the residual triglyceride, thus the conversion reaches 98 $\%$ in 20-30 min reaction time. We have used $50 \mathrm{~m}^{3}$ tanks for the esterification with intensive stirring. Separators for removing the glycerol phase, and the same volume of the separator was used to separate the neutralization agent and the ester phase which was mixed in a tube after exit of the first separator and before entering into the second one.

\subsection{Removal of the residual catalyst from the biodiesel (decontamination)}

In spite of the efforts to produce solid phase non-soluble alkaline catalysts or highly active acidic (super-acidic) catalysts (Di Serio et al, 2008; Leung et al., 2010; Soriano et al., 2009), the homogeneous catalytic ( $\mathrm{KOH}$ or $\mathrm{NaOMe}$ catalyzed) trans-esterification of vegetable oils have been the most commonly used method in the biodiesel industry (Huber et al., 2006). However, soap formation during the alkaline-catalyzed trans-esterification is the most problematic by-reaction. In case of low water and carboxylic acid containing vegetable oils the main source of the soap formation is the hydrolysis of the formed methyl esters during washing, which is a strongly $\mathrm{pH}$ dependent process. Thus the neutralization preceding the washing is an essential step to minimize the saponification by-reactions. The amount and type of the formed soap is strongly affected by the separation characteristics of the glycerol and the ester phase. The acid treatment is generally needed to start or quicken the phase separation process producing aqueous glycerol solution. It is well known that the distribution of the catalyst between the glycerol and the methyl ester phase is strongly depends on the temperature, type of the catalyst, excess of methanol and the composition of the two separated phases [Chiu et al., 2005; Di Felice et al., 2008; Zhou and Boocock, 2006). Table 2 shows the distribution of $1 \% \mathrm{KOH}$ and $0.5 \%$ of $\mathrm{H}_{2} \mathrm{SO}_{4}$ distribution at different temperatures depending on the amount of methanol at biodiesel : glycerol molar ratio of 1:3. 


\begin{tabular}{|c|c|c|c|c|c|c|c|}
\hline Catalyst & $\mathrm{T},{ }^{\circ} \mathrm{C}$ & $\mathrm{MeOH}, \mathrm{mol}$ & $\mathbf{K}$ & Catalyst & $\mathrm{T},{ }^{\circ} \mathrm{C}$ & $\mathrm{MeOH}, \mathrm{mol}$ & $\mathbf{K}$ \\
\hline \multirow{6}{*}{$\mathrm{KOH}$} & 25 & 0 & 98 & \multirow{6}{*}{$\mathrm{H}_{2} \mathrm{SO}_{4}$} & 25 & 0 & 60 \\
\hline & 25 & 3 & 95 & & 25 & 3 & 53 \\
\hline & 25 & 6 & 77 & & 25 & 6 & 46 \\
\hline & 75 & 0 & 47 & & 75 & 0 & 31 \\
\hline & 75 & 3 & 45 & & 75 & 3 & 28 \\
\hline & 75 & 6 & 35 & & 75 & 6 & 24 \\
\hline
\end{tabular}

Table 2. Distribution of the $\mathrm{KOH}$ catalyst between the ester and glycerol phase in the function of temperature and $\mathrm{MeOH}$ excess $\left(\mathrm{K}=\mathrm{C}_{\text {glycerol }} / \mathrm{C}_{\text {ester phase }}\right)$

It can be seen that increasing temperature increases the amount of the catalyst in the ester phase. The amount of dissolved methanol also increases the amount of dissolved catalyst. The $\mathrm{K}$ values of the distribution of methanol, however, 10.9 and 7.5 at 3 and 8.5 and 4.8 at 6 moles of methanol towards $3 \mathrm{~mol}$ of biodiesel and 1 moles of glycerol at 25 and $75{ }^{\circ} \mathrm{C}$, respectively. In the presence of $1 \% \mathrm{KOH}$, these values changed to 2.29, 1.64, 1.90 and 1.48, respectively.

Due to the room-temperature reaction, there is low catalyst and low methanol concentration in the ester phase, thus the amount of the required neutralization agent is also low. Considering the use of a continuous separator, the relative volumes of the separated phases should be adjusted between 10-1:1, so it is possible to use dilute (2\%) $\mathrm{KHSO}_{4}$ solution. The neutralization acts as the first washing step, when the potassium content in the biodiesel phase was proved to be up to $8 \mathrm{ppm}$ without further aqueous washing. Instead of mineral acids we used an acidic salt as hydrogen ion sources, namely, potassium hydrogen sulfate $\left(\mathrm{KHSO}_{4}\right)$. Potassium hydrogen sulfate has as strong acidic function as the pure sulfuric acid without the disadvantages of the sulfuric acid, e.g. it is a solid crystalline mass can be stored without risk and can be dissolved in water without extreme heat generation, and no acidic vapors as in the case of hydrochloric acid can be felt. Due to the low amount of soaps in the ester phase, the dissolved methanol content of the ester phase is lower than in case of the classical biodiesel technologies. Potassium hydrogen sulfate as a strong "acid" reacts with $\mathrm{KOH}$ catalyst and soaps easily and spontaneously as

$$
\mathrm{KOR}+\mathrm{KHSO}_{4}=\mathrm{K}_{2} \mathrm{SO}_{4}+\mathrm{HOR}
$$

where $\mathrm{R}=$ alkylcarbonyl radical (potassium soaps) or $\mathrm{H}(\mathrm{KOH})$. The aqeous $\mathrm{KHSO}_{4}$ solution decomposes soaps immediately without emulsion formation. The formed potassium sulfate is neutral, soluble in water, insoluble in the ester phase and has no phase transfer property at all. The concentration of the formed potassium sulfate is low $(\sim 2-3 \%)$, since dilute $\mathrm{KHSO}_{4}$ solutions is used for neutralization of the potassium compounds in the ester phase. The aqueous phase will contain potassium sulfate, glycerol, methanol, and other water soluble components. The dilute solution can easily be ion-exchanged with strong acidic cationic exchangers as Varion KSM resin. The glycerol and the methanol containing aqueous phase is a strong polar solution, thus regeneration and recycling of the $\mathrm{KHSO}_{4}$ should be taken place. However, stopping and controlling the operation of the ion exchanger at the stage of the hydrogen sulfate formation is difficult. Therefore, the $\mathrm{K}_{2} \mathrm{SO}_{4}$ containing material stream is divided into two equal parts. One part of the $\mathrm{K}_{2} \mathrm{SO}_{4}$ is ion-exchanged in a common way with the formation of $\mathrm{H}_{2} \mathrm{SO}_{4}$ solution (the 
$\mathrm{K}$-ions are bound by the resin phase). The dilute sulfuric acid is combined with the other stream of the $\mathrm{K}_{2} \mathrm{SO}_{4}$, when $\mathrm{KHSO}_{4}$ forms which can be recycled without further treatment (Kótai et al., 2008a).

$$
\mathrm{K}_{2} \mathrm{SO}_{4}+\mathrm{H}_{2} \mathrm{SO}_{4}=2 \mathrm{KHSO}_{4}
$$

The exhausted ion exchanger can be regenerated with the $20 \%$ sulfuric acid solution consumed also for the formal neutralization. The potassium sulfate solution obtained during the regeneration process of the ion exchanger resin can be used as a fertilizer component. The ion exchanger can be regenerated and used again several thousand times.

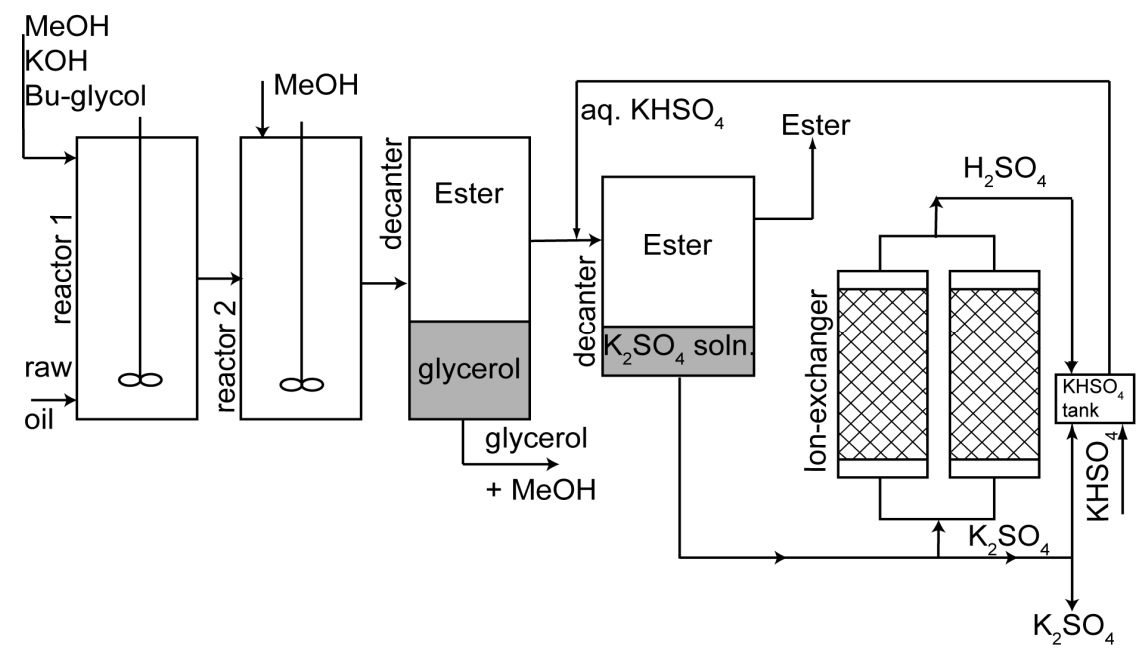

Fig. 2. Flow-sheet of biodiesel synthesis

However, the recycling of the $\mathrm{KHSO}_{4}$ solutions is recommended only 2-20 times due to the accumulation of glycerol and methanol in the aqueous $\mathrm{KHSO}_{4}$ solutions. The process flow is shown in Fig. 2.

The completely neutralized $\mathrm{KHSO}_{4}$ solution turns into $\mathrm{K}_{2} \mathrm{SO}_{4}$, therefore it can be used as a fertilizer component together with the $\mathrm{K}_{2} \mathrm{SO}_{4}$ originated from the ion exchange regeneration cycle. Similarly, the potassium hydroxide content of the glycerol phase may be utilized in the same way after processing its glycerol and methanol content with $\mathrm{H}_{2} \mathrm{SO}_{4}$ catalyst into fuel (see in Chapter 4.2). In this way, the starting potassium based catalyst $(\mathrm{KOH})$ is used not only as a catalyst but as a fertilizer source in an advantageous sulfate form, which helps to avoid the chloride accumulation in the soil and supplies the sulfur deficiency of the soil, especially in the case of rape plant cultures of high sulfur demand (Scherer, 2001).

\subsection{Trans-esterification of high acid containing vegetable oils}

Production of biodiesels from non-food quality vegetable oils with high fatty acid content is an important area of the biodiesel developments. The common alkaline catalysts cannot be used economically, because they reacts with the fatty acids and form soaps causing high catalyst consumption and a decrease in the catalyst activity. The alkali soaps are the cause of 
problems in the phase separation and the decreasing in the yield of esters. The calcium soaps do not dissolve in water and not surface active agents, do not cause problems in the phase separation and using calcium methanolate as catalyst in the trans-esterification of the vegetable oils is a well-known process (Lindquist, 1991). Due to the insolubility of $\mathrm{CaO}$ and $\mathrm{Ca}(\mathrm{OH})_{2}$ in methanol, the $\mathrm{CaO}$ and the $\mathrm{Ca}(\mathrm{OH})_{2}$ are known as less active or inactive compounds for the vegetable oil trans-esterification (Di Serio, et al., 2008), but the activation of calcium oxide to act as a catalysts in this reaction leads to good results (Kótai et al., 2006, $2008 \mathrm{~b}$ ). The free acid content of the vegetable oils and $\mathrm{CaO}$ were immediately reacted with formation of calcium soaps, and the $\mathrm{Ca}(\mathrm{OH})_{2}$ formed from the excess of $\mathrm{CaO}$ played role in the trans-esterification. The best results (quantitative conversion of triglycerides into methyl esters) was obtained by using calcium hydroxide (5.6 \%) prepared in situ by slaking of $\mathrm{CaO}$ at a 3:1 $\mathrm{CaO}$ to $\mathrm{H}_{2} \mathrm{O}$ mass ratio and at a 10:4 oil: methanol ratio for $1 \mathrm{~h}$ under reflux. Excess of $\mathrm{CaO}$ is essential in this reaction. Using half amount of catalyst and methanol, the conversion was $90 \%$ only, and $9 \%$ triglyceride and $1 \%$ diglyceride could be detected in the ester phase. In case of high fatty acid containing starting vegetable oils the calcium soaps formed is partially soluble in the methanol containing ester phase, thus after separation of the soap containing glycerol the ester phase was treated with a slight excess of concentrated sulfuric acid. The sulfuric acid has multiple roles in the system,

1. it forms calcium sulfate and releases the bound fatty acids

2. catalyzes the reaction of the liberated fatty acids and the methanol excess used in the trans-esterification

3. destroys the instable polyunsaturated compounds which could cause deposition in the engines

4. decreases the iodine number and the ash content in the ester phase

Since the optimal trans-esterification can be performed at 2-4 fold excess of methanol, the residual methanol content means a very high (30-60 fold) excess toward the liberated fatty acids taking part in the acid catalyzed trans-esterification (Khelevina 1968). The anhydrous $\mathrm{CaSO}_{4}$ formed in the neutralization step promotes the esterification reaction of the liberated fatty acids due to binding of the water formed in the equilibrium esterification reactions:

$$
\begin{gathered}
\mathrm{R}-\mathrm{COOH}+\mathrm{MeOH}=\mathrm{RCOOMe}+\mathrm{H}_{2} \mathrm{O} \\
\mathrm{CaSO}_{4}+0.5 \mathrm{H}_{2} \mathrm{O}=\mathrm{CaSO}_{4} \cdot 0.5 \mathrm{H}_{2} \mathrm{O}
\end{gathered}
$$

Although the calcium sulfate has di-hydrate, in this system only the hemihydrate has formed (Kótai et al., 2008b). The solid $\mathrm{CaSO}_{4} \cdot 0.5 \mathrm{H}_{2} \mathrm{O}$ can be used as sulfur fertilizer and improve the properties of unbound (sandy like) soils due to its binding properties with water (plaster of paris). During the removal of the polyunsaturated (Benjumea et al., 2011) labile compounds by sulfuric acid various compounds having acidic character form. The acid number of the ester phase is around $3.2 \mathrm{mg} \mathrm{KOH} / \mathrm{g}$ oil. It is essential to remove these acids from the ester phase. It has been tried with filtering this ester phase through calcium or iron carbonate containing mineral granulates. This method, however, have not been effective, and in case of calcium carbonate some oil soluble products were also formed which increased the ash content of the ester. By using Varion ADA type resin (alkylammonium type ion exchanger in $\mathrm{OH}$ form) the acidic constituent could easily be removed. The acid number was found to be $1.25 \mathrm{mg} \mathrm{KOH} / \mathrm{g}$ oil, practically the same as was found for this oil after complete vacuum distillation $(1.24 \mathrm{mg} \mathrm{KOH} / \mathrm{g}$ oil) (Kótai et al., 2008b). 


\section{Butanol as raw material in biodiesel production}

By using of butanol as blending material for gasoline and diesel fuels has many advantages towards fuel ethanol (Andersen et al., 2010; Bruno et al., 2009, Duck and Bruce, 1945, Workman et al., 1983), additionally, it can also be used as reactive component in biodiesel production. Butanol can substitute methanol as an alcohol for esterification (Wahlen et al., 2008; Nimcevic et al., 2000, Stoldt and Dave, 1998), it can be an acetal forming compounds for transforming of acetone or other ketones into acetals, or can easily be converted to butyraldehyde for the conversion of glycerol formed during trans-esterification of oils into 1,3-dioxane- or dioxolane type fuel additives (Silva et al., 2010)

\subsection{Butanol as blending or reactive component in biodiesel production}

The butanol or the butanol - acetone - ethanol mixture produced in the ABE fermentation have been tested already during the World War II as a blending components for gasoline powered engines (Duck and Bruce, 1945). The engines can be powered with gasoline containing butanol up to $40 \%$ without any technical modification of the engine. The characteristics of pure butanol and $\mathrm{ABE}$ solvent mixtures as gasoline or diesel fuel additives have been tested in detail. Generally, the blended mixtures produce almost the same power and thermal efficiency as the gasoline (Schrock and Clark, 1983). The same time the blending has a positive effect via substantially decreasing the $\mathrm{NO}_{x}$ content of the exhaust gases.

Since the modern mobile agricultural equipment used in the production of biomass is mostly diesel powered, both ethanol and butanol have been tested for using them as blending components of diesel fuels. By the addition of butanol or ABE blends to diesel fuel the thermal efficiency could be increased, the exhaust gas temperatures are lowered and the soot formation is decreased. The operational parameters of the engine have been studied in detail (Workman et al., 1983). Butanol proved to be an alternative diesel fuel blend. By using butanol as a reactive component in vegetable oil butyl ester preparation or preparation of butanol based acetals, the residual butanol content does not has to be removed from the reaction mixture because it can act as blending component. A special case of the extraction of butanol from aqueous solutions during $\mathrm{ABE}$ fermentation is when the extractant is vegatable oil (Welsh and Williams, 1989). The butanol to be extracted can be reacted easily with the extractant. Since the vegetable oil alkyl esters are also extractants of the butanol (Crabbe et al., 2001, Ishizaki et al., 1999), this method can easily be integrated into a catalyst free supercritical trans-esterification technology, when the partially trans-esterified vegetable oil is recycled into the extraction process until its complete transformation into butylester. Since the butanol content extracted in the last step does not need to be separated from the butyl ester product, the method is advantageously integrated into the waste free biodiesel production system.

The use of butanol as a reactive component in biodiesel production has a lot of advantage. First of all, the convenient base catalyzed reaction takes place in homogeneous phase, thus the reaction is faster, the separation of the glycerol is better and the temperature of the reaction can be lowered. The excess of the butanol does not need to be removed from the ester phase. The viscosity of the butylester mixture prepared from soya oil was found to be $4.50 \mathrm{~mm}^{2} / \mathrm{s}$ at $40^{\circ} \mathrm{C}$, the cetane index was 69 . The cloud point of butyl-biodiesel is $-3^{\circ} \mathrm{C}$. The flash point and pour point were found to be 44 and $-13{ }^{\circ} \mathrm{C}$, respectively (Wahlen et al., 2008). Since butanol reacts with free acids faster than methanol, the high acid containing vegetable oils (free fatty acid content of vegetable oils varies from 7 to $40 \%$ ), the waste 
cooked oils or other high free acid containing oils can also be used as raw materials. These high free fatty acid containing oils could not be trans-esterified economically with methanol and basic catalysts, and in the presence of acidic catalysts the reactions are very slow.

Solid phase heterogeneous catalysts have not widely been available for use them in industrial scale for these type of oils (Di Serio et al., 2008). The acid catalysts simultaneously catalyze the esterification of the free acids and the trans-esterification of the glycerides however, butyl esters are formed more easier than methyl esters (Wahlen et al., 2008). Methanol, ethanol, n-propanol and n-butanol have been reacted with oleic acid as a model for free fatty acids at 4:1 alcohol/acid molar ratio in the presence of $5 \%$ sulfuric acid (as catalyst) at $80{ }^{\circ} \mathrm{C}$ for $16 \mathrm{~min}$. The conversion was best (90\%) for n-butanol, and the worst in the case of methanol (85\%). The difference in trans-esterification activity of $\mathrm{C}_{1-4}$ alcohols in the presence of $\mathrm{H}_{2} \mathrm{SO}_{4}$ catalyst is more significant. The methanol can react with the soybean oil (10:1 methanol/bound fatty acid ratio) at $60{ }^{\circ} \mathrm{C}$ with $5 \%$ sulfuric acid as catalyst only with $2 \%$ conversion within $32 \mathrm{~min}$. By using 12:1 alcohol/soybean oil ratio and $80{ }^{\circ} \mathrm{C}$ temperature, the methanol and ethanol gave $18 \%$ conversion in $16 \mathrm{~min}$, while the propanol and butanol showed $50 \%$ conversion during the same time. The reaction of butanol with vegetable oils at a mixed feedstock containing oleic acid and soya oil with a ratio of 5:1-1:5 required minimum 2:1 butanol/fatty acid (free and bound) molar ratio at $110{ }^{\circ} \mathrm{C}$ in the presence of $5 \% \mathrm{H}_{2} \mathrm{SO}_{4}$ catalyst. Using microwave heating at 6:1 butanol/soybean oil ratio in the presence of $3 \% \mathrm{H}_{2} \mathrm{SO}_{4}$, a $98 \%$ conversion was achieved within 50 min. By using microwave heating the trans-esterification reaction of the vegetable oils with butanol can be performed without any catalyst under supercritical conditions (Geuens et al., 2008). Since the butanol boiling point is higher than methanol boiling point, the reactions takes place at higher temperatures without using extremely large pressures. The best results were achieved at $310{ }^{\circ} \mathrm{C}$ and 80 bar pressure in $\mathrm{SiC}$ coated tube reactor. The lack of the catalyst results very a small amount of glycerol without soap formation. The excess of butanol does not need to be separated from the ester phase or can be flashed out from the glycerol phase for recycling.

By using n-butanol instead of methanol and butoxylation of the unsaturated alkyl chain improve the ratio of the fossil energy used to produce a unit of renewable energy source. The highly unsaturated oils cause gum and deposit formation, but their epoxidation with peroxy-acetic acid and contacting the epoxides with n-butanol in the presence of $2 \%$ sulfuric acid as catalyst at $80 \mathrm{C}^{\circ}$, results $100 \%$ conversion of the epoxides. The selectivity is $87 \%$, and the $46 \%$ conversion of the unsaturated alkyl chains does not cause an increase in the cloud point (Smith et al., 2009). As it can be seen, the butanol increases the amount of the biofuel produced from raw vegetable oil, by molar weight increasing referring to methyl esters (Table 3., Nimcevic et al., 2000), by incorporating butoxy groups into the unsaturated alkyl chains and by mixing the excess butanol with the formed fuel.

\begin{tabular}{|l|c|c|c|}
\hline \multirow{2}{*}{ Ester } & \multicolumn{2}{|c|}{ Combustion value } & $\begin{array}{l}\text { Alcohol molar } \\
\text { fraction in the } \\
\text { ester molecule }\end{array}$ \\
\cline { 2 - 4 } & $\mathbf{M J} / \mathbf{k g}$ & $\mathbf{M J} / \mathbf{k m o l}$ & 8.7 \\
\hline Methyl & 39.83 & 14156 & 12.2 \\
\hline Ethyl & 40.03 & 14787 & 18.4 \\
\hline Butyl & 40.52 & 16103 & \\
\hline
\end{tabular}

Table 3. Alcohol inputs in the production of biodiesel 
In addition to these possibilities, in case of high acid containing raw vegetable oils, the acid content can also be transformed into butyl-type biofuel and does not need to be recovered as soaps. The abovementioned possibilities can be applied as parts of an integrated system together with other techniques to improve biofuel production, e.g. during the conversion of vegetable oils into methyl esters, the free fatty acids liberated from calcium soaps can be esterified with butanol instead of methanol as well (see Chapter 3.3).

\subsection{Transformation of the wastes of butanol and biodiesel production into fuel}

Glycerol is a very hygroscopic material and its combustion heat is low due to its high oxygen content. Neither its viscosity nor its hygroscopic nature or the miscibility properties indicate direct applicability as a fuel component. However, the glycerol is a reactive compound, thus the glycerol formed in the biodiesel synthesis can be transformed into lower oxygen containing compounds or to their mixture by various reactions (Guerro-Perez et al., 2009, Mota et al., 2009). In order to decrease the oxygen content of the products formed, the most reliable way is water elimination. It can be performed by reduction or by condensation reactions performed with reactants containing $\mathrm{O}=$ or HO-functions. The structure and reactivity ensure a series of water elimination (intra or intermolecular) reactions and formation of a variety of compounds.

The glycerol can act as a multifunctional primary and secondary alcohol and can easily be dimerized or polymerised into compounds with residual alcohol functions and alcoholic type reactivity. The glycerol can also be reacted with various other alcohol derivatives (with methanol residue from trans-esterification or with ethanol or butanol from $\mathrm{ABE}$ fermentation) into ethers. Transformation into cyclic acetals by using oxo-compounds e.g. acetone from $\mathrm{ABE}$ fermentation or acetone - acetaldehyde - butyraldehyde mixtures from the oxidation of not separated ABE products can also be performed. The formed acetals are cyclic dioxolane and dioxane type primary or secondary alcohols, or their stereoisomers (if $\mathrm{R}_{1}$ and $\mathrm{R}_{2}$ are not the same), respectively (Ferreira, et. al., 2010; Kótai and Angyal, 2011).

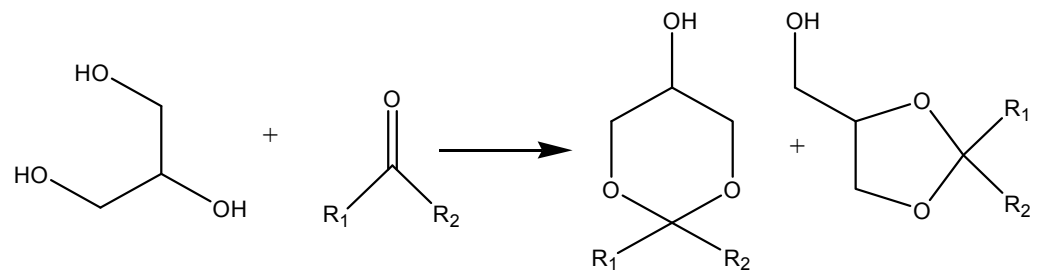

By partial oxidation of the mixture of primary alcohols from the first $A B E$ fraction containing acetone, ethanol and butanol to aldehydes, a mixture of alcohols and oxocompounds can be prepared. By using the waste glycerol containing methanol from the biodiesel production (or formaldehyde from the methanol oxidation) can provide a complex reaction mixture which can be condensed into an un-separated multicomponent mixture of various oxygenates with lower oxygen content than the starting glycerol. This mixture does not require complete separation into components or individual compounds to use it as a fuel. The reaction has been studied in the presence of various acidic catalysts as sulfuric acid, sulfonated styrene-divinyl-benzene copolymers and p-toluene-sulfonic acid. All of the catalyst gave similar results, the main product have been the 1,3-dioxolane derivatives. Various other components have also been formed in 1-2 \% amount of each. The low-boiling fractions contain mainly the starting alcohols, acetone and dialkoxypropane derivatives, the 
higher fractions contain mainly 2,2-dimethyl-4-hydroxymethyl-1,3-dioxolane, its mixture with the starting alcohols and the formed dialkoxypropanes. The 2,2-dimethyl-5-hydroxy1,3-dioxane has appeared only in the distillation residue because its boiling point is higher than $120^{\circ} \mathrm{C}$. In the acetalization of acetone with glycerol the two possible isomers 1,3dioxolane or 1,3-dioxane ring containing products can also be formed in the 1,2- or 1,3-type cyclization reactions. The molar ratio of the dioxolane / dioxane and the yields slightly depend on the type of the acidic catalyst. The composition of a typical reaction mixture is illustrated in Table 4. The main product is the 2,2-dimethyl-4-hydroxymethyl-1,3-dioxolane, a smaller amount of the 2,2-dimethyl-5-hydroxy-1,3-dioxane and dialkoxy-propanes are also formed. Two mixed methoxy-group containing acetals are formed, as well. Thus, it seems to be probably that the primarily formed 2,2-dimethoxypropane has reacted with the higher primary alcohols. In order to increase the complexity of the mixture, which is an optimal situation for fuels, the glycerol - $\mathrm{MeOH}$ mixture was mixed with the first un-separated fraction of the butanol production which contains $\mathrm{EtOH}$, acetone and $\mathrm{BuOH}$, and reacted with various oxo- compounds prepared from the abovementioned alcohols by oxidation $\left(\mathrm{CH}_{2} \mathrm{O}, \mathrm{CH}_{3} \mathrm{CHO}\right.$ and butyraldehyde).

\begin{tabular}{|l|l|c|c|c|}
\hline Compound & Alcohol & Fraction & Peak area & B.p. range \\
\hline $\mathrm{MeC}(\mathrm{OMe}) 2 \mathrm{Me}$ & $\mathrm{MeOH}$ & $\mathrm{I}-\mathrm{IV}$ & 1 & $58-99^{\circ} \mathrm{C}$ \\
\hline $\mathrm{MeC}(\mathrm{OMe})(\mathrm{OEt}) \mathrm{Me}$ & $\mathrm{MeOH}, \mathrm{EtOH}$ & $\mathrm{I}-\mathrm{IV}$ & 2 & $58-99^{\circ} \mathrm{C}$ \\
\hline $\mathrm{MeC}(\mathrm{OEt}) 2 \mathrm{Me}$ & $\mathrm{EtOH}$ & $\mathrm{III}, \mathrm{IV}$ & 1 & $71-99^{\circ} \mathrm{C}$ \\
\hline $\mathrm{MeC}(\mathrm{OMe})(\mathrm{OBu}) \mathrm{Me}$ & $\mathrm{MeOH}, \mathrm{BuOH}$ & $\mathrm{I}-\mathrm{IV}$ & 1 & $58-99^{\circ} \mathrm{C}$ \\
\hline $\begin{array}{l}\text { 2,2-Me } \\
\text { 3-dioxolane }\end{array}$ & glycerol & III-VI & 88 & $71-120^{\circ} \mathrm{C}<$ \\
\hline $\begin{array}{l}\text { 2,2-dimethyl-5-OH-1, } \\
\text { 3-dioxane }\end{array}$ & glycerol & VI & 2 & $120^{\circ} \mathrm{C}<$ \\
\hline
\end{tabular}

Table 4. The acetals formed in the reaction of ABE solvents and glycerol containing methanol with Varion KSM acidic ion exchanger catalyst at $3 \mathrm{~h}$ reflux

It can be seen that from the same molar amounts of the alcohols the acetone prefers the reaction with the glycerol, or the dialkoxy-propanes formed reacts with the glycerol via reformation of the alcohols.

In this way, the waste stream from $\mathrm{ABE}$ and biodiesel production with or without oxidative treatment results an un-separated mixture containing various alcoholic and oxo-components which can react with each other in various water elimination reactions to from a variety of lower oxygen containing acetal/ether type compounds. The formed mixture contains components with a wide boiling range. Table 5 contains the product distribution in a mixture formed in the reaction of 1-1 equivalents of acetone, acetaldehyde, n-butyaldehyde and formaldehyde by 1 equivalent of glycerol and 2-2 equivalents of $\mathrm{MeOH}, \mathrm{EtOH}$ and $\mathrm{BuOH}$ with Varion KSM sulfonated ion exchanger as catalyst under $3 \mathrm{~h}$ reflux. The reaction mixture has been separated into five fractions to study the distribution of each component formed and the starting material in the fractions. Depending on the reaction conditions, molar ratios of each reactant and the catalyst, the product distribution can be varied. Two isomers of 2-alkyl-4-hydroxymethyl dioxolanes are formed which have different boiling points. As an example, the effect of glycerol formal on the properties of the biodiesels can be seen in Table. 6. (Puche, 2009) 
An Integrated Waste-Free Biomass Utilization

System for an Increased Productivity of Biofuel and Bioenergy

\begin{tabular}{|c|c|c|c|c|}
\hline Compounds & Alcohol & Oxo-reactants & Fraction & Peak area \\
\hline \multicolumn{5}{|l|}{ Dialkoxi-methanes } \\
\hline$(\mathrm{MeO})_{2} \mathrm{CH}_{2}$ & $\mathrm{MeOH}$ & $\mathrm{CH}_{2} \mathrm{O}$ & I-II & 2 \\
\hline$(\mathrm{EtO})_{2} \mathrm{CH}_{2}$ & $\mathrm{EtOH}$ & $\mathrm{CH}_{2} \mathrm{O}$ & I-IV & 5 \\
\hline $\mathrm{BuOCH}_{2} \mathrm{OMe}$ & $\mathrm{BuOH}, \mathrm{MeOH}$ & $\mathrm{CH}_{2} \mathrm{O}$ & I-III & 15 \\
\hline $\mathrm{BuOCH}_{2} \mathrm{OEt}$ & $\mathrm{BuOH}, \mathrm{EtOH}$ & $\mathrm{CH}_{2} \mathrm{O}$ & I-IV & 14 \\
\hline$(\mathrm{BuO})_{2} \mathrm{CH}_{2}$ & $\mathrm{BuOH}$ & $\mathrm{CH}_{2} \mathrm{O}$ & II-V & 5 \\
\hline \multicolumn{5}{|l|}{ Dialkoxyethanes } \\
\hline$(\mathrm{BuO})(\mathrm{MeO}) \mathrm{CHCH}_{3}$ & $\mathrm{BuOH}, \mathrm{MeOH}$ & $\mathrm{CH}_{3} \mathrm{CHO}$ & I-IV & 1 \\
\hline$(\mathrm{BuO})_{2} \mathrm{CHCH}_{3}$ & $\mathrm{BuOH}$ & $\mathrm{CH}_{3} \mathrm{CHO}$ & IV-V & 2 \\
\hline \multicolumn{5}{|l|}{ Dialkoxybutanes } \\
\hline$(\mathrm{BuO})_{2} \mathrm{CHCH}_{2} \mathrm{CH}_{2} \mathrm{CH}_{3}$ & $\mathrm{BuOH}$ & $\mathrm{PrCHO}$ & IV-V & 2 \\
\hline \multicolumn{5}{|l|}{ 1,3-Dioxolanes (2 isomers) } \\
\hline 2-Me-4- $\mathrm{CH}_{2} \mathrm{OH}-1,3$-dioxolane & glycerol & $\mathrm{CH}_{3} \mathrm{CHO}$ & $\mathrm{I}-\mathrm{V}$ & 6 \\
\hline 2-Me-4- $\mathrm{CH}_{2} \mathrm{OH}-1,3$-dioxolane & glycerol & $\mathrm{CH}_{3} \mathrm{CHO}$ & $\mathrm{V}$ & 4 \\
\hline 2-Pr-4- $\mathrm{CH}_{2} \mathrm{OH}-1,3$-dioxolane & glycerol & $\mathrm{PrCHO}$ & $\mathrm{V}$ & 12 \\
\hline 2-Pr-4- $\mathrm{CH}_{2} \mathrm{OH}-1,3$-dioxolane & glycerol & acetone & IV-V & 11 \\
\hline \multicolumn{5}{|l|}{ 1,3-Dioxanes } \\
\hline 2-Me-5-OH-1,3-dioxane & glycerol & $\mathrm{CH}_{3} \mathrm{CHO}$ & IV-V & 2 \\
\hline 2-Pr-5-OH-1,3-dioxane & glycerol & $\mathrm{PrCHO}$ & $\mathrm{V}$ & 3 \\
\hline
\end{tabular}

Table 5. The identified components of the reaction between biodiesel waste and partially oxidized ABE production waste streams in the presence of Varion KSM catalyst

\begin{tabular}{|l|c|c|c|c|c|}
\hline & \multicolumn{5}{|c|}{ RME + glycerol formal } \\
\hline Glycerol formal content & 0 & $0.5 \%$ & $1 \%$ & $5 \%$ & $10 \%$ \\
\hline Density, $\mathbf{g} / \mathbf{c m}^{\mathbf{3}}$ & 0.8592 & 0.8620 & 0.8631 & 0.8711 & 0.8802 \\
\hline Freezing point, ${ }^{\circ} \mathbf{C}$ & -7 & -16 & -21 & -21 & -21 \\
\hline Viscosity at $\mathbf{- 1 0} \mathbf{C}^{\circ}, \mathbf{c S t}$ & Solid & No data & 548.2 & 343.3 & No data \\
\hline
\end{tabular}

Table 6. Effect of glycerol formal on properties of methyl ester of rapeseed oil

Not only acetals, but other ether type components can also be used as fuel blends. The condensation products formed with alcoholic functions can be used for further acetal formation. The dioxolane and dioxane type compounds with alcoholic function groups can be esterified or etherified in a further reaction into other valuable products (Jalinski, 2006). 

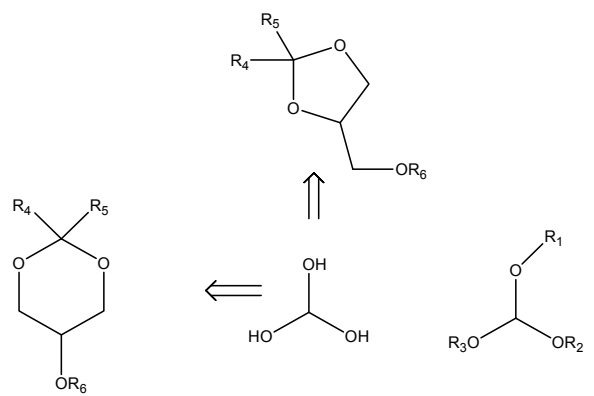

The general scheme for transformation of glycerol into fuel components with $\mathrm{ABE}$ components is given by eqn. (6), where $\mathrm{R}_{1}, \mathrm{R}_{2}$ and $\mathrm{R}_{3}$ are $\mathrm{Me}, \mathrm{Et}, \mathrm{Bu}, \mathrm{CH}_{3} \mathrm{C}(\mathrm{O})-, \mathrm{C}_{3} \mathrm{H}_{7} \mathrm{C}(\mathrm{O})$-, $\mathrm{R}_{4}$ and $\mathrm{R}_{5}$ are $\mathrm{H}, \mathrm{Me}, \mathrm{Pr}$, and $\mathrm{R}_{6}$ means $\mathrm{Me}, \mathrm{Et}, \mathrm{Bu}, \mathrm{CH}_{3} \mathrm{C}(\mathrm{O})_{-}, \mathrm{C}_{3} \mathrm{H}_{7} \mathrm{C}(\mathrm{O})$ or other groups derived from the alcohol-type glycerol condensation products. Transformation of all three hydroxyl groups of the glycerol into alkoxy groups (methoxy, ethoxy or butoxy), or esterifying them with low carbon chain carboxylic acids (acetic acid, butyric acid) decrease the hydrophil nature and oxygen content and increase the combustion heat, the miscibility with fuel. Thus, these compounds are advantageous fuel additives (Mota et al., 2009). Since ethanol, butanol, methanol, acetic and butyric acid are products/by-products and intermediates of the $\mathrm{ABE}$ fermentation or biodiesel production, these reactions are candidates for integration into a complex biomass utilization system. The intermediate acetic and butyric acid can also be used as acylation agents for the cyclic acetals, and in this way all product of the ABE fermentation become fuel component. Not only these organic acids but carbonic acid can also acts as acid residue in the esterified products. The carbonate compounds prepared form acetals formed from n-butyraldehyde or acetone and glycerol lowering the soot and the particulate formation during ignition of the diesel fuels (Delfort, 2004). Alkylation or acylation of free hydroxy-groups in 1,3-dioxolane and dioxane type fuel blends increases their solubility with two order of magnitudes (Jalinski, 2006)].

It is obvious, that glycerol which has primary and secondary alcohol functions, and can be condensed with itself to different kind of polyglycerols (Barrault et al., 1998). Polyglycerols can be obtained at high temperature vapor phase reaction over solid catalysts as alkali and alkaline earth metal hydroxides or carbonates, zeolites, La-ion-exchanged zeolites and ion-exchanger resins (Barrault et al., 1998). In the presence of resins, the main product is the diglycerol.<smiles>OCC(O)COCC(O)CO</smiles><smiles>OCC(O)COC(CO)CO</smiles><smiles>OCC(CO)OC(CO)CO</smiles> 
Since the glycerol has hydroxyl groups with various reactivity, depending on the catalyst and the reaction conditions, various dimers and even more type of oligomers and polymers can be formed. By using these dimers (oligomers) in acetal forming reactions, the complexity of fuel mixture can be further increased.

Not only water elimination, but increasing carbon chain length can decrease the relative oxygen content and increase the combustion heat and improve the fuel properties. Selective etherification of glycerol or the free alcoholic function groups of the condensates formed from the glycerol. The alcohol functions of glycerol or other alcohols formed during polymerization of glycerol or acetal production can easily be alkylated by reaction with isoalkenes (Klepacova et al., 2003). Trans-esterification of crude soya oil with methanol in the presence of $\mathrm{NaOH}$ catalyst, then separating the glycerol phase reacted with the mixture in the presence of Amberlyte-15 acidic ion exchanger catalysts for 2 when isobutylene converts the glycerol into ethers. The mixture formed contains $9 \%$ triether, $47 \%$ diether, $21 \%$ mono-ether, $5 \%$ unreacted glycerol, $14 \%$ isobutylene and $4 \%$ methyl esters. By separating and recycling the starting materials and the mono-ethers the residue can be mixed with the ester phase formed in the trans-esterification when a mixture is formed containing $12 \%$ ethers and $88 \%$ methyl esters. Its clouding point is below $0{ }^{\circ} \mathrm{C}$ and having a viscosity of $5.94 \mathrm{cSt}$ which is lower with $9{ }^{\circ} \mathrm{C}$ and $0.5 \mathrm{cSt}$, respectively, if this parameters are compared to the ester phase without the addition of glycerol ethers (Barrault et al., 1998).

The oxygenate mixtures produced in the abovementioned ways ensures that a very complex mixture of compounds could be manufactured, in which all components of the ABE fermentation and biodiesel production turn into fuel component. These blending materials have very advantageous properties, decrease the viscosity, decrease the pouring point and soot formation and improve the cetane number. In this way, vegetable oil ester (mainly butyl ester), butanol and acetal or other oxygenate mixture containing biodiesels are formed with much higher production efficiency compared to the classical vegetable oil methyl esters. Thus, our technology can provide an aromatic hydrocarbon-free fuel which can be used even in highly populated large cities. Since biodiesels, fossil diesels and the gasolines can be mixed with pure butanol up to an amount of $40 \%$ without influencing the fuel properties, and these oxygenates can also be used around in an amount of $20 \%$, these new kind of fuel mixtures can provide a solution for the EU demand (incorporation of $20 \%$ biocomponent into fuels until 2020).

\section{Other aspects of the integrated biomass utilization system}

It is an obvious question that which bioalcohol should be used for the replacement of methanol in biodiesel production, or it is worth to change the ethanol blends of fuels to butanol which has much better fuel properties and energy content than the ethanol.

Comparison of technical and economical assessment for corn and switch grass fermented by yeast into ethanol and C. acetobutylicum into butanol showed (Pfromm et al., 2010) that biobutanol production is not competitive with ethanol production. As an example, the carbon balances for corn are illustrated in Fig. 3. However, involving new technologies, new raw materials (e.g. sugar sorghum) and the extractive fermentation processes combined with immobilized cell techniques, and decrease the production cost by means of the new separation technologies, the butanol becomes competitive as blending or reactive component in biofuel production. 


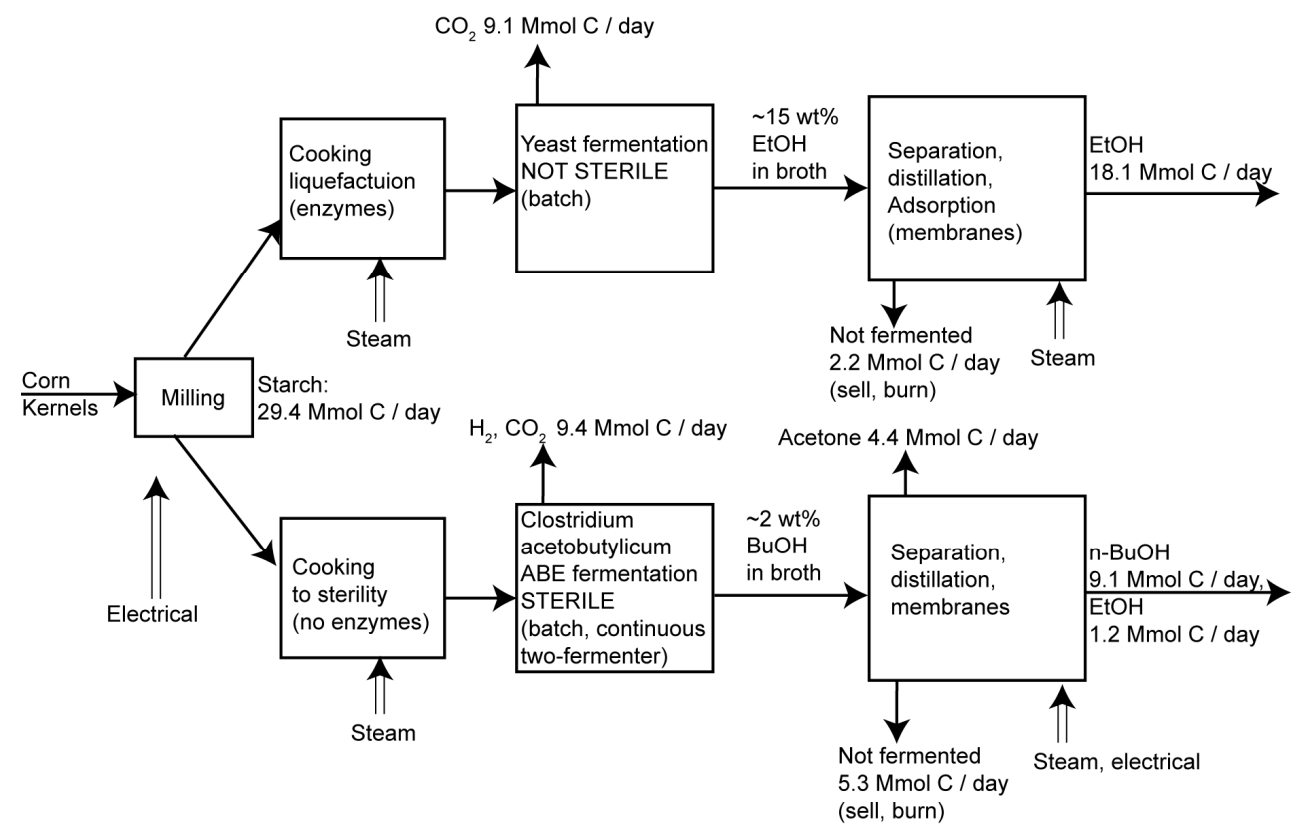

Fig. 3. Comparison of the carbon balances in the fermentation of corn into ethanol (yeast) and $\mathrm{ABE}$ (bacteria)

\subsection{New trends in biobutanol technology}

The industrial production of biobutanol has roughly a 100 years history, here only some new trends are reviewed in order to indicate the new perspectives of the biobutanol technology. The so called ABE fermentation produces acetone, butanol and ethanol in a ratio of about 2:1:7 or 3:1:6 depending on the bacteria and the fermentation conditions. A small amount of acetic acid and butyric acid are also formed. The starting materials are $C_{5}$ and $C_{6}$ sugars, e.g. starch or cellulose hydrolizates, and there are some bacteria strain as well which can utilize cellulose directly. The main problem of the biotechnological butanol production is the toxicity of the solvents formed (mainly the butanol) towards the microorganism (Costa, 1981). The most intensively studied area of the developments is the genetic engineering to produce butanol tolerant bacterium strains or produce less sensitive genetically modified yeast and saving the microorganism from the toxic effects, e.g. by immobilization and capsulation of the bacteria (Park et al., 1989), or by the removal of the accumulated solvents before reaching the toxicity level (Papadopoulos and Linke, 2009; Schmidt et al., 1988;). Combination of the methods provides a good chance to start a continuous ABE fermentation (Hartmeier et al., 1991, Ishii et al., 1985, Kótai and Balogh, 2011). Since the energy demand of the butanol recovery from the dilute solution is one of the main cost factor extraction with a suitable solvent or adsorption on a cheap heterogeneous carrier can be candidates for the development of energy efficient butanol production. Due to the low adsorption capacity of known adsorbents like activated carbon, or the affinity of solid sorbents towards water allowed only utilization at low level. The extraction seemed to be more effective, but the solvents have to meet serious requirements like: 
- Non-toxic to the microorganism and high stability,

- High distribution coefficient and selectivity with respect to the product,

- Low viscosity and solubility in the aqueous phase,

- Gravitation separation by density difference,

- Large interfacial tension and low tendency to emulsify the broth,

- High boiling point difference with respect to ABE solvents and low price

By using immobilized microorganism and in situ extraction the continuous production of butanol and ABE solvents can be performed easily, especially, if the integrated biomass utilization system ensures the sugar solution from sorghum processing. Thus, a large amount of ballast materials from corn or starch hydrolysis which increase the dry material content of the mash can be avoided The main problems are;

1. that the solvents which have high selectivity to the ABE solvents are very toxic to the microorganisms,

2. the best distribution coefficients for butanol found among the non-toxic solvents is only 3.5 (oleyl alcohol). In order to apply the high distribution coefficient of a toxic solvent associated with the requirements of the continuous production of butanol, a special system to produce ABE solvents has been developed.

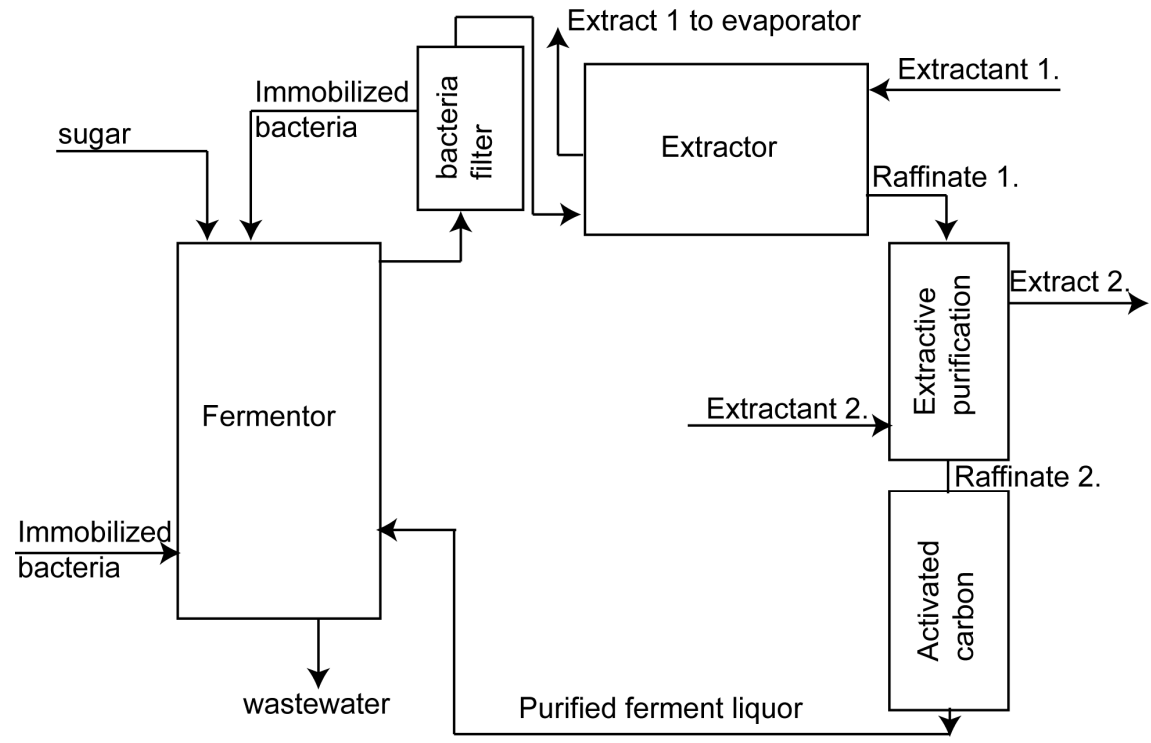

Fig. 4. Flow-sheet of continuous butanol fermentation with outer extraction

Heptanal, which has distribution coefficient for butanol of $K_{B}=11.3$ has been selected for the new technique. The toxicity of the heptanal is avoided via a by-pass extraction and a post-extractive purification for removal of traces of extractant from the ferment liquor before recycling it to the fermentation. The flow-sheet of particular method can be seen in Fig. 4. The technology using immobilized bacteria and heptanal as solvent is under development now. After starting the fermentation and before reaching the toxic level of butanol, a part of the ferment liquor is pumped out into a counter-current extractor filled with heptanal. The extraction is a continuous process. It means that the raffinate phase is 
contacted with another non-toxic solvent and/or a sorbent which removes the toxic solvent from the raffinate before recycling it into the fermentation. It should be noted here, that in case of heptanal the distribution of the ABE solvents can be considered to be advantageous.

\begin{tabular}{|c|c|c|}
\hline Solvent & Heptanal & Oleyl alcohol \\
\hline Acetone & 1.65 & 0.40 \\
\hline Ethanol & 1.01 & 0.10 \\
\hline Butanol & 11.13 & 3.75 \\
\hline
\end{tabular}

Table 7. Distribution coefficients of ABE solvents

The boiling point of heptanal is higher than the ABE solvents, thus the evaporation of the heptanal is avoided and does not require energy, By using a special fermentor - extractor system (Fig. 5) the extract phase containing the ABE solvents are contacted with another heptanal phase having a smaller volume (1/10-1/5) than the volume of the primary extract. The contact takes place through a special porous wall based on a pumicite - cement composite (Kótai and Balogh, 2011; Kótai et al., 2011.).

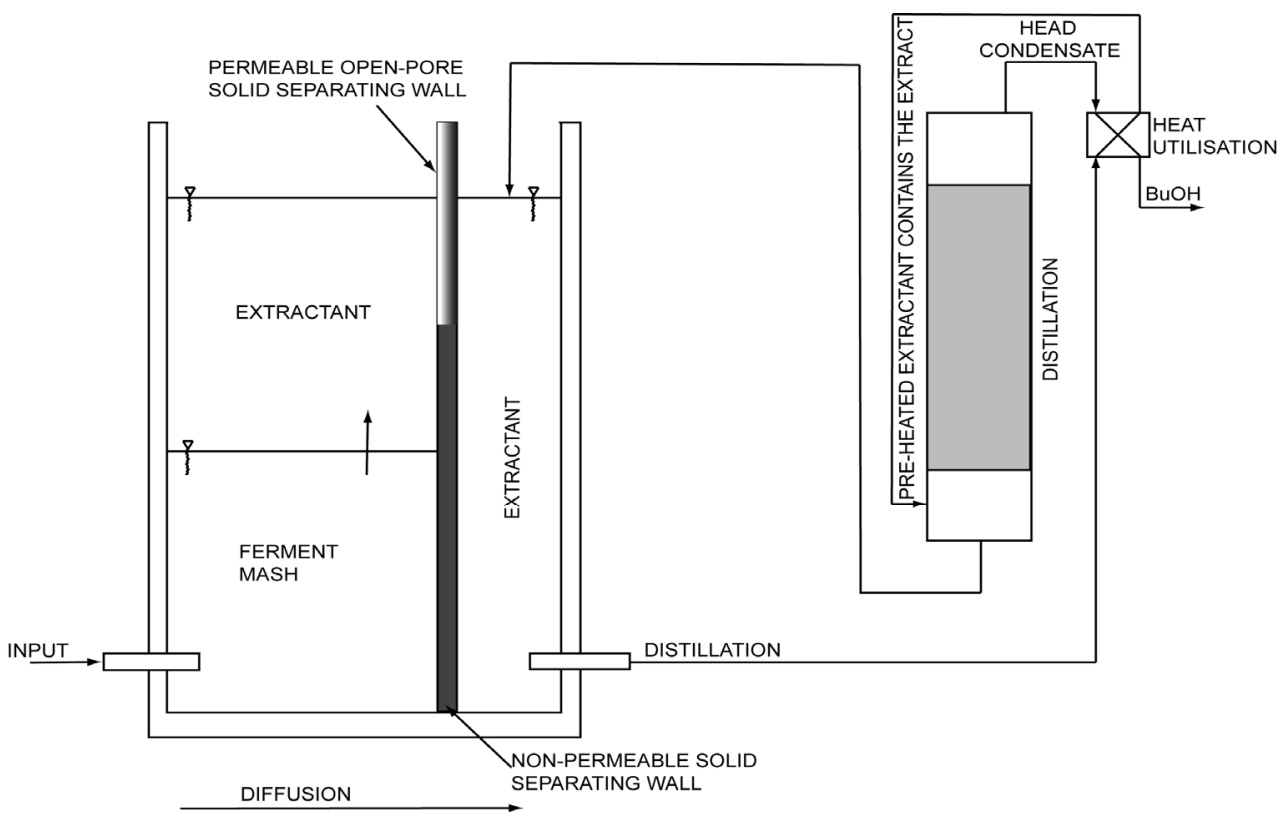

Fig. 5. Fermentor with composite wall

The porous material absorbs the solvents as a sponge, and it acts as a liquid transmitting media. There is no physical mixing only the diffusion controls the distribution of the solvents at the two sides of the wall. In order to keep the concentration difference as driving 
force, the ABE solvents is produced continuously at the A side (including the extraction step) and the extracted solvents are continuously removed at the B side of the wall, e.g. vacuum distillation, sorption by solid solvents as sulfonated styrene-divinyl-benzene copolymers (Kótai and Balogh, 2011), or with other methods. Due to their higher affinity towards water than the $\mathrm{ABE}$ solvents these copolymers ca not remove the $\mathrm{AB}$ solvents from the water directly. The Varion KSM sulfonated styrene-divinylbenzene copolymer can absorb the following amount of solvents (Kótai and Balogh, 2011)

\begin{tabular}{|c|c|c|c|}
\hline Solvent & Amount, $\mathbf{g} / \mathbf{1 0 0 g}$ & Solvent & Amount, $\mathbf{g} / \mathbf{1 0 0 g}$ \\
\hline Water & 87 & acetone & 40 \\
\hline $\mathrm{MeOH}$ & 75 & heptanal & 35 \\
\hline $\mathrm{EtOH}$ & 73 & Oleyl alcohol & 35 \\
\hline $\mathrm{BuOH}$ & 63 & Hexane & 30 \\
\hline
\end{tabular}

Table 8 . The adsorbed amount of solvents by solid sorbent based on sulfonated polymer

By using waste ion-exchangers, metal-containing activated carbons or metal-free carbons were prepared by leaching of metals from these metal-containing carbons [Kótai and Angyal, 2011], which are candidates as selective spherical sorbents with low hydrodynamic resistance for removing residual extractants and absorb the contaminants occurring in small amount in the ferment liquor. The Fe-containing sorbent are magnetic and could be separated very easily (without filtering) with an electromagnet (Kótai and Angyal, 2011). Elastic waste tires were also sulfonated for the preparation of sulfonated organic polymers to absorb butanol from organic media (Kótai and Balogh, 2011).

The supplement of the continuous reactor with sugar solution from the sorghum processing results a much cleaner technology than the process using the corn mash containing a lot of solid ballast material. Additional advantage of the method is the small volume of the B extract, because the small volume of invaluable solvents (water) needs small volume and investment of the distillation unit. A rough comparison of the energy and material balance shows, that selecting the appropriate bacteria and conditions, it is possible to reach the almost maximal theoretical utilization of glucose $(0.37 \mathrm{~g}$ butanol/g glucose), so the amount of waste water and the energy to produce a unit of butanol in principle can be decreased to $25-50 \%$.

Combination of these techniques with new developments in membrane technologies, mainly with selective membrane separation and pervaporation (Liu et al., 2005; Thongsukmak \& Sirkar), can provide a feasible butanol production technology.

\subsection{Recycling of ash from biomass power plants}

Combustion of biomass to produce energy (heat or electricity) always leaves back ash in various amount and composition depending on the biomass used as raw materials in the furnaces. This ash highly alkaline due to its potassium carbonate content $(\mathrm{pH}>10)$. Therefore it cannot be used directly as a fertilizer; only very small amount can be applied even for acidic soils. Since the ash contains all microelements and non-volatile elements in the amount absorbed and used by the plants harvested from the given area, their amount and ratio is optimal for the plant. Its insoluble content (e.g. phosphates) can be converted via digestion to utilizable material. In addition, it can be also supplemented with nitrogen fertilizers or other additives. In this way the processed ash becomes a useful material called 
eco-fertilizer (Angyal et al., 2006). In order to ensure the waste free technological viewpoints, the biomass power plant ash has to transform into fertilizer. It has been known for a long time that the alkaline ash can be neutralized with mineral acids, when potassium containing fertilizers are formed. However, these methods are difficult to perform technically, due to the large volume of gas formed in these reactions. Roughly 150 normal $\mathrm{m}^{3}$ of carbon dioxide evolves in the reaction of 1 ton of ash with intensive foaming. A biomass power plant with electric capacity of $50 \mathrm{MW}$ produces roughly 50-60 tons ash/day which means producing of $>300$ normal $\mathrm{m}^{3}$ of $\mathrm{CO}_{2}$ gas/h. Furthermore, a very large volume of dilute fertilizer solution is produced, thus the cost of transportation is very high. The evaporation of the solution is not feasible. In order to solve these problems and ensure recycling the ash components for sustainable biomass production, a new technology has been developed for the neutralization of the biomass power plant ashes. This method ensures complete digestion of potassium and phosphorus content of the ash and decreases the $\mathrm{K}$ and $\mathrm{P}$ fertilization costs which are essential in the case of plants with fast metabolism such as sugar sorghum or energy grass. The nitrogen supplement is the only one which should be ensured in a usual way with the addition of $\mathrm{N}$ fertilizers. In this way the sulfur deficiency of the soils, or extreme sulfur demand as in case of oily plants like rape can also be satisfied (Scherer, 2001).

The new method based on the reaction of sulfuric acid and the biomass ash in a long quasi-closed tube reactor equipped with a screw for moving the reaction mixture. The reaction substantially proceeds during the mixture motion from the one end of the reactor to the other. This technology ensures not only continuous production of neutralized ash, but other important changes also appear in the chemical constitution of the starting ash. Normally, concentrated sulfuric acid does not wet the ash and does not react with it at all, their mixing can be proceed without $\mathrm{CO}_{2}$ evolution. The reaction starts only in the presence of water. The mortar like mass prepared from the ash/limestone mixture and cc. sulfuric acid are mixed with water and reacted in the tube reactor. The reaction starts only after the dilution of the sulfuric acid. The most advantageous concentration is $\sim 50 \%$ (of sulfuric acid) when the carbonates reacts in a self-sustainable way due to producing water in the neutralization reactions. The key element in the reaction is the quasi-closed tube reactor. During moving the mortar like mass toward the opened end of the tube reactor, the neutralization reaction takes place and $\mathrm{CO}_{2}$ gas evolves as usual. However, the reaction mass acts as a plug which ensures that the formed $\mathrm{CO}_{2}$ gas cannot released from the reactor. The in situ evolved $\mathrm{CO}_{2}$ gas makes micro-bubbles in the material, because of the overpressure of the quasi-closed equipment, and the swelled mass fills out the tube reactor. However, the wall of the reactor and the reaction mass as a plug ensures an overpressure within the reactor. Due to the overpressure no fizzing out occurs within the reactor and the micro-bubbles of the carbon dioxide gas are kept in the mortar-like mass. If the amount of the mass is adjusted to be less in its volume than the volume of the reactor, the mass is blown up due to the evolved gas and fills completely the space within the reactor. The carbon dioxide micro-bubbles have a slight overpressure, thus leaving the tube reactor at the opened end, the gas leaves the semi-solidified mass and the places of the micro-bubbles becomes opened pores. Technologically this method ensures processing of the ash with sulfuric acid in a small volume of continuously operated tube reactor having only a volume of $\sim 3$ times larger than the volume of the ash that can be processed $(\sim 60-80$ times larger reactors as used in the classical neutralization methods do not 
needed (Angyal et al, 2006). Since the formed mortar like mass dries and solidifies easily, after granulating or pelletizing into the usual shape of solid fertilizers, the formed ecofertilizer can be spread as solid by common facilities.

This method of neutralization has numerous advantages towards the classical neutralization technologies, not only the formation of solid fertilizer instead of dilute liquids, and thus avoiding the high volume expensive reactors during manufacturing, but from chemical viewpoints as well. Normally, the ash formed from straw and energy grass contains a mixed potassium calcium carbonate (Buetschliite), $\mathrm{K}_{2} \mathrm{Ca}\left(\mathrm{CO}_{3}\right)_{2}$ as main components, the second most important phase is the $\mathrm{KCl}$, and $\mathrm{K}_{2} \mathrm{CO}_{3}$ and $\mathrm{K}_{2} \mathrm{SO}_{4}$ can also be detected by powder $\mathrm{X}$ ray diffraction. Similar amount of magnesium hydroxide and sodium carbonate can also be detected. The ratio of potassium chloride and sulfate depends on the soil composition, and the fertilization and type of fertilizer used $\left(\mathrm{KCl}\right.$ or $\left.\mathrm{K}_{2} \mathrm{SO}_{4}\right)$ during the production of the wheat of course. Expressing the important metal content in the form oxides are as it follows: $\sim 40 \%$ of $\mathrm{K}_{2} \mathrm{O}, \sim 10 \% \mathrm{CaO}, 3.5 \% \mathrm{MgO}$ and $2.5 \%$ of $\mathrm{Na}_{2} \mathrm{O}$. The straw contains a lot of chlorides $(\sim 7 \%)$, the other anions as sulfate and carbonate expressed in $\mathrm{SO}_{3}$ and $\mathrm{CO}_{2}$ are $\sim 10$ $\%$ and $\sim 20 \%$, respectively. The potassium-calcium carbonate (or potassium and calcium carbonate as well) easily reacts with diluted $(\sim 50 \%)$ sulfuric acid, but not only the expected $\mathrm{K}_{2} \mathrm{SO}_{4}$ and $\mathrm{CaSO}_{4}$ but their double salts as syngenite $\left(\mathrm{K}_{2} \mathrm{Ca}\left(\mathrm{SO}_{4}\right)_{2} \cdot \mathrm{H}_{2} \mathrm{O}\right)$ and polyhalite $\left(\mathrm{K}_{2} \mathrm{Ca}_{2} \mathrm{Mg}\left(\mathrm{SO}_{4}\right)_{4} \cdot 2 \mathrm{H}_{2} \mathrm{O}\right)$ are formed as main products. The syngenite is less soluble (but not completely insoluble) in water and has ion-exchange properties toward ammonium ion, because due to their similar sizes of potassium and ammonium ions they can substitute each other in the structure of this compound.

$$
\mathrm{K}_{2} \mathrm{Ca}\left(\mathrm{CO}_{3}\right)_{2}+2 \mathrm{H}_{2} \mathrm{SO}_{4}=\mathrm{K}_{2} \mathrm{Ca}\left(\mathrm{SO}_{4}\right)_{2} \cdot \mathrm{H}_{2} \mathrm{O}+\mathrm{H}_{2} \mathrm{O}+2 \mathrm{CO}_{2}
$$

The excess of sulfuric acid is neutralized to $\mathrm{pH}=6$ with limestone powder and can be used as simple and general potassium and sulfate fertilizer which has opened pore structures which can absorb water and keep it in the pores, this way increasing the water retaining capacity of the soil. This fertilizer contains soluble phosphates and microelements previously digested by the sulfuric acid treatment. Furthermore, via controlling the amount of the calcium carbonate powder in the last step of the manufacturing, acidic (sub-neutralized), neutral or alkaline (over-neutralized) fertilizers can also be produced. No liquid or solid waste form in this technology, all the used components are built into the structure of the product. Since the water absorbing capacity of these materials, due to the porosity controlled by the synthesis conditions is very high (50-120\% of its mass), it is obvious, that not only water but various aqueous solutions can also be absorbed in these pores. This behavior opens new perspectives, namely absorbing different other fertilizers, e.g. nitrogen fertilizers, insecticides, or any other solutions of important compounds which should be injected into the soils.

The most common nitrogen fertilizer is the ammonium nitrate, however, the metal-doped $\mathrm{NH}_{4} \mathrm{NO}_{3}$ production has serious problems because the ammonium nitrate is prilled from the melt, and the melted ammonium nitrate is easily exploded due to the catalytic effect of metal compounds. Thus, these metal microelements cannot be added to the melted $\mathrm{NH}_{4} \mathrm{NO}_{3}$ before prilling. Using ammonium nitrate solutions, the metals compounds can be added in the required amounts without any risk to the porous granulated eco-fertilizer. Although drying after the absorption of the aqueous solutions (e.g $\mathrm{NH}_{4} \mathrm{NO}_{3}$ solutions) requires extra energy, but the complete process energetically is still more advantageous, due to the 
following considerations. Ammonium nitrate solution is prepared in an exothermic reaction of a $\sim 65 \%$ of nitric acid with ammonia gas, when an aqueous solution of $\mathrm{NH}_{4} \mathrm{NO}_{3}$ solution (roughly $80 \%$ ) is formed. Evaporation of this solution at high temperature leads to the melt of ammonium nitrate which is prilled in the next step of manufacturing. Since we use the $\mathrm{NH}_{4} \mathrm{NO}_{3}$ solution, which is contacted with the granules, the water removal, without melting of the $\mathrm{NH}_{4} \mathrm{NO}_{3}$, requires less energy than the final step of the solid $\mathrm{NH}_{4} \mathrm{NO}_{3}$ manufacturing. This concentrated $\mathrm{NH}_{4} \mathrm{NO}_{3}$ solution has acidic character, and easily react with the syngenite and other components of the eco-fertilizer. The concentrated $\mathrm{NH}_{4} \mathrm{NO}_{3}$ solutions are not only physically absorbed and imbibed in the pores of the eco-fertilizer, but chemically reacts with its components, as well.

$$
\mathrm{K}_{2} \mathrm{Ca}\left(\mathrm{SO}_{4}\right)_{2} \cdot \mathrm{H}_{2} \mathrm{O} \text { (syngenite) } \quad\left(\mathrm{NH}_{4}\right)_{2} \mathrm{Ca}\left(\mathrm{SO}_{4}\right)_{2} \cdot \mathrm{H}_{2} \mathrm{O} \text { (koktait) }
$$

The potassium ions can be substituted with ammonium ion with the formation of partially or completely ion-exchanged syngenite-like isomorphous compounds. The completely substituted product is called to be koktaite, $\left(\mathrm{NH}_{4}\right)_{2} \mathrm{Ca}\left(\mathrm{SO}_{4}\right)_{2} \cdot \mathrm{H}_{2} \mathrm{O}$, which is less soluble in water, thus releases nitrogen slowly into the soil (Angyal et al., 2006; Coates and Woodward, 1988; Von Maessenhausen et al., 1988). The formed potassium nitrate transformed into a solid solution with the excess of the ammonium nitrate, the typical composition of this product was the $\mathrm{K}_{0.27}\left(\mathrm{NH}_{4}\right)_{0.73} \mathrm{NO}_{3}$. The koktaite and $\mathrm{NH}_{4}$-syngenites are sparingly soluble in water, thus the ammonium ion concentration liberated in the presence of water is constant at a given temperature and ionic strength of sulfate ion. Since not the full amount of the ammonium ion is liberated, no damages to the plant and losses by washing away, respectively occur even if using in high doses. When the plant absorbs the ammonium-ion from the soil, due to the equilibrium conditions, a part of the solid will dissolve and supply the water with a new amount of ammonium ion. Since the equilibrium concentration is closely constant, the amount of water will control the amount of the released ammonium ion, namely, the release of the ammonium ion from this koktaite type compounds is controlled by raining or irrigating. In drought situation, when there is no absorption of ammonium ion from the soil by the plant, there is no dissolution of ammonium syngenites and releasing ammonium ion which would be decomposed by the soil bacteria as it happens in case of water soluble ammonium ion containing fertilizers. Besides ammonium nitrate, other fertilizer components can also be used to adjust the main element concentrations, such as $\mathrm{K}, \mathrm{P}$ or $\mathrm{N}$, and to change the available form of these elements in various chemical compounds. The $\mathrm{K}_{2} \mathrm{HPO}_{4}$ does not react at all with other components of the ash. It is interesting, that ammonium salts as $\mathrm{NH}_{4} \mathrm{Cl}$ and $\left(\mathrm{NH}_{4}\right)_{2} \mathrm{SO}_{4}$ cannot transform the syngenite completely into $\left(\mathrm{NH}_{4}\right)_{2} \mathrm{SO}_{4}$, even if the ammonium sulfate is in excess, but in the presence of urea, the transformation is complete. Both $\mathrm{KCl}$ and $\mathrm{K}_{2} \mathrm{SO}_{4}$ decompose the ammonium syngenite, but the mixture of the $\mathrm{K}_{2} \mathrm{SO}_{4}$ and the $\mathrm{NH}_{4} \mathrm{Cl}$ produces $\left(\mathrm{NH}_{4}\right)_{2} \mathrm{Ca}\left(\mathrm{SO}_{4}\right)_{2} \cdot \mathrm{H}_{2} \mathrm{O}$. Thus, the main factor is probably the ammonium to potassium ion ratio. There is an important difference between the behavior of the potassium sulfate and potassium chloride. The latter compound is more reactive, and $\mathrm{KCl}, \mathrm{KNO}_{3}$ and $\mathrm{NH}_{4} \mathrm{MgCl}_{3}$ are also formed in its presence. Using various additives not only the ratio of the agriculturally important elements (K, P, N, S) are controlled but their chemical forms can also be altered. Using various kind of soil bacteria and supplementary materials to ensure theirs intensive growing is another possibility for nitrogen-fixation in the treated area. By using the eco-fertilizer technology supplemented 
with absorbing of aqueous liquids ensures the recycling of the by-product of the biomass power plant providing energy and electricity for the biofuel (biodiesel and biobutanol and supplemented) plants. This way we can sustain the production of the renewable energy plants, e.g. sugars sorghum, while the soil quality is maintained and improved, respectively.

\section{Conclusion}

By proper selection of biomass available from a given area, the sugar and energy sources, and the relative amount of the vegetable oil produced can be adjusted. In order to decrease the processing cost of raw materials into sugar containing mash for fermentation plants, the classical sugar sources as corn can be replaced with sugar sorghum, which can be processed similar to sugarcane. Combustion of the residual biomass in power plants or their digestion into biogas depend on the water and protein content of the residue and the heat or electricity demand of fuel-producing (biodiesel, biobutanol, acetals, etc.) or waste processing (fertilizer production) plants. Generally, it is more advantageous to use biomasses of high protein and water content in biogas plants. Burning the biogas or by using it as fuel in gas-engines the amount of heat and electricity can be controlled. Wastes of high cellulose content can be advantageously burned in power plants, sometimes after drying with the low heat value warm water streams of energy production. Wastes of fuel production can be utilized by combination these two methods of energy production. The ash and the solid residues from biomass power plants can be utilized as fertilizers by mixing them with potassium sulfate or calcium sulfate formed during recovery of the catalyst $\left(\mathrm{KHSO}_{4}\right.$ or $\left.\mathrm{H}_{2} \mathrm{SO}_{4}\right)$ in biodiesel or acetal plants. Finally, there are two other wastes. The first is $\mathrm{K}_{2} \mathrm{SO}_{4}$ from the biodiesel technology, and the other is the ash from the combustion. Beyond the integration of energy producing and consuming plants and controlling the ratio of the raw materials and the type of the energy (heat or electricity), the production technology is also to be changed mainly in biodiesel, biobutanol and fertilizer plants. In this way the energy consumption of each technological step can be decreased.

\section{References}

Andersen, V. F., Anderson, J. E., Wallington, T. J., Mueller, S. A. \& Nielsen, O. J., Energy \& Fuels, Vol. 24, (2010), pp. 2683-2691. ISSN 0887-0624

Angyal, A., Hujber, O., Kótai, L., Legeza, L. \& Sajó, I. E., HU Patent Appl. 0600390, 2006.

Arlie, J.-P., Revue de l' Institute Francais du Petrole, Vol. 38, No.2. (1983), pp. 251-257. ISSN 0020-2274

Barrault, J., Pouilloux, Y., Vanhove, C., Cottin, K., Abro, S. \& Clacens, J. M., Chemistry and Industry, Vol. 75, (1998), pp. 13-23. ISSN 0009-3068

Benjumea, P., Agudelo, J. R. \& Agudelo, A. F., Energy \& Fuel, Vol. 25, (2011), pp. 77-85. ISSN 0887-0624

Boocock, D. G. B., Konar, S. K. \& Sidi, H., Journal of the American Oil Chemists Society, Vol 73 (1996), pp. 1247-1251, ISSN 0003-021X 
Boocock, D. G. B., Konar, S. K., Mao, V. \& Sidi, H., Biomass \& Bioenergy, Vol.11, No.1. (1996), pp. 43-50, ISSN: 0961-9534

Boocock, D. G. B., Konar, S. K., Mao, V., Lee, C. \& Buligan, S., Journal of the American Oil Chemists Society, Vol. 75, (1998), pp. 1167-1172, ISSN 0003-021X

Bruno, T. J., Wolk, A. \& Naydich, A., Energy \& Fuel, 23 (2009), pp. 2295-2306. ISSN 08870624

Coates, R. V. \& Woodard, G. D., Journal of Science of Food \& Agriculture, Vol. 14, No.6, (1963), pp. 398-404, ISSN 0022-5142

Costa, J. M., Proc. Ann. Biochem. Eng. Symp. 11th, (1981), pp. 83-90.

Crabbe, E., Nolasco-Hipolito, C., Kobayashi, G., Sonomoto, K. \& Ishizaki, A., Process Biochemistry, Vol. 37, (2001), pp. 65-71, ISSN 0032-9592.

Delfort, B., Durand, I., Jaecker, A., Lacome, T., Montagne, X. \& Fabrice, P., US 7097674, 2004.

Di Serio, M., Tesser, R., Pengmei, L. \& Santacesaria, E., Energy \& Fuels, Vol. 22, (2008), pp. 207-217. ISSN 0887-0624

Duck, J. T. \& Bruce, C. S., Journal of Research of the National Bureau of Standards, (1945), pp.439465, ISSN: 0160-1741.

Ferreira, P., Fonseca, I. M., Ramos, A. M., Vital, J. \& Castanheiro, J. E., , Applied Catalysis B. Environmental, Vol.98, (2010), pp. 94-99, ISSN 0926-3373

Fu B., \& Vasudevan, P. T., Energy \& Fuels, vol. 23, (2009), pp. 4105-4111. ISSN 08870624

Geuens, J., Kremsner, J. M., Nebel, B. A., Schober, S., Dommisse, R. A., Mittelbach, M., Tavernier, S., Kappe, C. O. \& Maes, B. U. W., Energy \& Fuels, vol. 22, (2008), pp. 643645. ISSN 0887-0624

Guan, G., Kusakabe, K., Sakurai, N. \& Moriyama, K., Fuel, Vol. 88, (2009), pp. 81-6, ISSN 0016-2361

Guan, G., Sakurai, N. \& Kusakabe, K., Chemical Engineering Journal, Vol.146, (2009), pp. 3026, ISSN 1385-8947.

Guerro-Perez, M. O., Rosas, J. M., Bedia, J., Rodriguez-Mirasol, J. \& Cordero, T., Recent Patents on Chemical Engineering, Vol. 2, (2009), pp. 11-21. ISSN 2211-3347

Hartmeier, W., Buecker, C. \& Wallrath, J., Biochem. Bioeng., 2nd Int. Symp., Stuttgart, (1991), pp. 236-241.

Hill, J., Nelson, E., Tilman, D., Polasky, S. \& Tiffany, D., Proceedings of the National Academy of Sciences Vol. 103, No. 30, (2006), pp. 11206-11210, ISSN 1091-6490.

Huber, G. W., Iborra, S. \& Corma, A., Chemical Reviews, Vol. 106, (2006), pp. 4044-4098, ISSN 0009-2665

Ishii, S., Taya, M., Kobayashi, T., Journal of Chemical Engineering of Japan, Vol. 18, No.2, (1985), pp. 125-130, ISSN 0021-9592

Ishizaki, A., Michiwaki, S., Crabbe, E., Kobayashi, G., Sonomoto, K. \& Yoshino, S., Journal of Bioscience and Bioengineering, Vol. 87, No. 3, (1999), pp. 352-356 ISSN 1389-1723

Jalinski, T. J., WO 2006/084048 A1, 2006

Khelevina, O. G. \& Kanyaev, N. P., Izvestiya Vysshikh Uchebnii Zavedenii, Khimiya $i$ Khimicheskaya Tekhnologiya, Vol. 11, No.2, (1968), pp. 166-170, ISSN 05792991. 
Klepacova, K., Mravec, D., Hajekova, E. \& Bajus, M., Petroleum \& Coal, Vol. 45, (2003), pp. 5457, ISSN 1335-3055

Kótai, L. \& Angyal, A., Research Report, GOP 1.1.1., Axial-Chem Ltd., 2011.

Kótai, L., Angyal, A., Somogyi, I., Bihatsi, L., May, Z., Gömöry, Á. \& Tamics, E., HU 08/00437A, 2008.

Kótai, L. \& Balogh, J., Research Report, GOP 1.1.1., Kemobil Co., 2011.

Kótai, L., Gömöry, Á., Gács, I., Holly, S., Sajó, I. E., Tamics, E., Aradi, T. \& Bihátsi, L., Chemistry Letters, Vol. 37, No. 10, (2008), pp. 1076-7, ISSN 0366-7022

Kótai, L., Szépvölgyi, J., Tamics, E., HU 11/00286 A. 2011.

Kótai, L., Tamics, E., Sas, J., Deme, P., Gömöry, Á. \& Aradi, T., HU 06/00886A, 2006.

Leung, D. Y. C., Wu, X. \& Leung, M. K. H., Applied Energy, Vol. 87, (2010), pp. 1083-1085, ISSN 0306-2619

Lindquist, C.-J., WO91/15452, 1991.

Liu, F., Liu, L., Feng, X., Separation \& Purification Technology, Vol. 42, (2005), pp. 273-282. ISSN 1383-5866

Maeda, K., Kuramochi, H., Asakuma, Y., Fukui, K., Tsuji,. T., Osako, M. \& Sakai, S., Chemical Engineering Journal, Vol. 169, (2011), pp. 226-30, ISSN 1385-8947.

Meng, Z., Jiang, J. \& Li, X., Taiyangneng Xuabao,Vol.30, No.3, (2009), pp. 385-389. ISSN 02540096

Mota, C. J. A., da Silva, C. X. A. \& Goncalves, V. L. C., Quimica Nova Vol.32, No.3, (2009), pp. 639-648, ISSN 0100-4042

Nimcevic, D., Puntigam, R., Woergetter, M. \& Gapes, J. R., Journal of the American Oil Chemists Society, Vol. 77, No. 3, (2000), pp. 275-280. ISSN 0003-021X

Papadopoulos, A. I. \& Linke, P., Chemical Engineering and Processing: Process Intensification, Vol. 48, (2009), pp. 1047-1060, ISSN 0255-2701.

Park, C.-H., Okos, M. R. \& Wankat, P. C., Biotechnology and Bioengineering, Vol. 34, (1989), pp. 18-29, ISSN 0006-3592

Pimentel, D. \& Petzek, T. W., Natural Resources Research, Vol. 14, No.1, (2005), pp. 65-76, ISSN 1520-7439.

Pfromm, P. H., Amanor-Boadu, V., Nelson, R., Vadlani, P. \& Madl, R., Biomass and Bioenergy, Vol. 34, (2010), pp. 515-524, ISSN 0961-9534

Puche, J. D., US 7637969B2, 2009.

Scherer, H. W., European Journal of Agronomy, Vol. 14, (2001), pp. 81-111, ISSN 11610301

Schmidt, A., Windsperger, A. \& Friedl, A., US 4749495, 1988.

Schrock, M. D. \& Clark, S. J., Transactions of the ASAE (1983), pp. 723-727, ISSN 00012351

Silva, P. H. R., Goncalves, V. L. C. \& Mota, C. J. A., Bioresource Technology, Vol. 101, (2010), 101, pp. 6225-6229, ISSN 0960-8524.

Smith, P. C., O'Neill, B. K., Ngothai, Y. \& Nguyen, Q. D, Energy \& Fuels, Vol. 23, (2009), pp. 3798-3803, ISSN 0887-0624

Soriano, N. U., Jr., Venditti, R. \& Argyropoulos, D. S., Fuel, Vol. 88, (2009), pp. 560-565, ISSN 0016-2361

Stoldt, S. H. \& Dave, H., EP 0860494 A1, 1998. 
Thongsukmak, A. \& Sirkar, K. K., Journal of Membrane Science, Vol. 302, (2007), pp. 45-58, ISSN 0376-7388.

Von Maessenhausen, W., Czikkely, V. \& Jung, J., US4883530 B2, 1988.

Wahlen, B. D., Barney, B. M. \& Seefeldt, L. C., Energy \& Fuels, Vol. 22 (2008), pp. 4223-28. ISSN 0887-0624.

Welsh, F. W. \& Williams, R. E., Journal of Chemical Technology \& Biotechnology, Vol. 46, No. 3, (1989), pp. 169-78, ISSN 0268-2575

Workman, J.P., Miller, G. L. \& Smith, J. L., Transactions of ASAE, 1983, 642-645, ISSN 00012351 


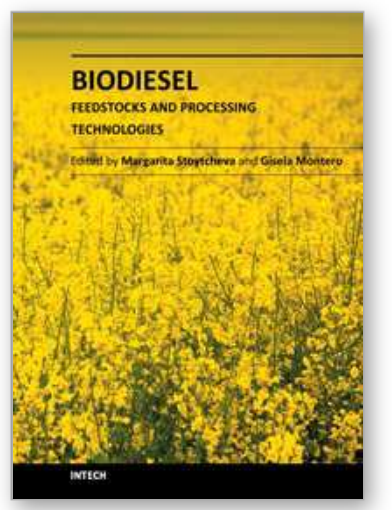

\author{
Biodiesel - Feedstocks and Processing Technologies \\ Edited by Dr. Margarita Stoytcheva
}

ISBN 978-953-307-713-0

Hard cover, 458 pages

Publisher InTech

Published online 09, November, 2011

Published in print edition November, 2011

The book "Biodiesel: Feedstocks and Processing Technologies" is intended to provide a professional look on the recent achievements and emerging trends in biodiesel production. It includes 22 chapters, organized in two sections. The first book section: "Feedstocks for Biodiesel Production" covers issues associated with the utilization of cost effective non-edible raw materials and wastes, and the development of biomass feedstock with physical and chemical properties that facilitate it processing to biodiesel. These include Brassicaceae spp., cooking oils, animal fat wastes, oleaginous fungi, and algae. The second book section: "Biodiesel Production Methods" is devoted to the advanced techniques for biodiesel synthesis: supercritical transesterification, microwaves, radio frequency and ultrasound techniques, reactive distillation, and optimized transesterification processes making use of solid catalysts and immobilized enzymes. The adequate and upto-date information provided in this book should be of interest for research scientist, students, and technologists, involved in biodiesel production.

\title{
How to reference
}

In order to correctly reference this scholarly work, feel free to copy and paste the following:

László Kótai, János Szépvölgyi, János Bozi, István Gács, Szabolcs Bálint, Agnes Gömöry, András Angyal, János Balogh, Zhibin Li, Moutong Chen, Chen Wang and Baiquan Chen (2011). An Integrated Waste-Free Biomass Utilization System for an Increased Productivity of Biofuel and Bioenergy, Biodiesel - Feedstocks and Processing Technologies, Dr. Margarita Stoytcheva (Ed.), ISBN: 978-953-307-713-0, InTech, Available from: http://www.intechopen.com/books/biodiesel-feedstocks-and-processing-technologies/an-integrated-waste-freebiomass-utilization-system-for-an-increased-productivity-of-biofuel-and-bio

\section{INTECH}

open science / open minds

\section{InTech Europe}

University Campus STeP Ri

Slavka Krautzeka 83/A

51000 Rijeka, Croatia

Phone: +385 (51) 770447

Fax: +385 (51) 686166

www.intechopen.com

\section{InTech China}

Unit 405, Office Block, Hotel Equatorial Shanghai

No.65, Yan An Road (West), Shanghai, 200040, China

中国上海市延安西路65号上海国际贵都大饭店办公楼 405 单元

Phone: +86-21-62489820

Fax: +86-21-62489821 
(C) 2011 The Author(s). Licensee IntechOpen. This is an open access article distributed under the terms of the Creative Commons Attribution 3.0 License, which permits unrestricted use, distribution, and reproduction in any medium, provided the original work is properly cited. 